\title{
The Impact of Wealth on Consumption and Retirement Behaviour in the UK
}

\author{
David Blake \\ The Pensions Institute \\ BirkBeCK COLLEGe \\ UNIVERSITY OF LONDON \\ GRESSE ST. \\ LONDON W1T 1LL \\ United KingDOM \\ TEL: +44 (0)2076316410 \\ EMAIL: D.BLAKE@BBK.AC.UK
}

\begin{abstract}
Housing and pension wealth are shown to be important determinants of personal sector consumption and retirement behaviour in the UK. Housing and state pension wealth have a positive effect on consumption, while private pension wealth promotes greater savings. Greater private defined benefit pension wealth encourages earlier retirement, while greater defined contribution pension wealth has the effect of delaying retirement. State pension wealth appears to have no effect on the retirement decision. Other variables relating to income, labour market and demographic status and spillovers from other sectors are also shown to be important. The consumption equation forecasts the late 1980s boom and the early 1990s slump in the UK better than other models that disregard housing and pension wealth. A particularly important cause of the boom was the huge private pension fund surpluses that accrued as a result of the stock market boom of the 1980s.
\end{abstract}

KEYWORDs. Merton model, consumption, retirement, financial wealth, housing wealth, pension wealth, human capital.

JEL. C51, C52, C53, E21, G23, J26

Acknowledgement 1. I am grateful to Malcolm Crawford, Paul Johnson, Costas Meghir, David Miles, James Pemberton, Ron Smith and Ian Tonks for comments and suggestions on earlier drafts of the paper. 


\section{The Impact of Wealth on Consumption and Retirement Behaviour in the UK}

\section{INTRODUCTION}

Over the years, the specification of mainstream aggregate consumption functions has become increasingly more sophisticated. From a humble beginning as a simple relationship between current consumption and current income, additional independent variables have been added (e.g. income uncertainty, the relative price of nondurables, unemployment rate, inflation rate) and wealth has joined income as a principal explanatory variable. Even the wealth measure has become more comprehensive over time, starting with liquid assets and subsequently being extended to include durables, financial and housing assets. However, one key component of wealth has not been adequately assessed in mainstream aggregate consumption functions and that is pension wealth. Yet pension wealth is enormous, accounting for $50 \%$ of all personal wealth in the UK, for example.

However a different literature, originating with [31]Feldstein (1974), has used the aggregate consumption function with various types of pension wealth to test, amongst other things, various hypotheses in public finance, such as whether Ricardian equivalence holds. At the same time, there have been criticisms both of the measures of pension wealth and of the underlying model (namely the extended life cycle model) used to test these hypotheses.

This paper brings together a number of different strands from the above literatures. Its principal aim is to examine the impact on consumption and retirement behaviour of various components of wealth, especially pension wealth. It does so within the context of a well-specified econometric model that is developed from a specific economic model underlying optimising consumption behaviour. ${ }^{1}$ Finally, it uses superior measures of the wealth variables than have hitherto been used. For example, all the pension wealth estimates are based on appropriate actuarial methods as explained in [11]Blake and Orszag (1999).

The resulting model should be seen in the light of [47]Hendry's (1994) comments: '[T] he explanation of predictive failure in the consumption function [in the late 1980s] lies in the behaviour of excluded factors rather than changes in included factors that were inappropriately modelled. Thus the focus [in his paper] shifts to interactions with financial deregulation and uncertainty ... The impact of such additional variables as unemployment and interest rates was tested without any positive evidence resulting, but demographic change, illiquid wealth and house prices were not tested for relevance, although they could all potentially matter. Thus a great deal remains to be learnt about the behaviour of this much studied aggregate.' (p.87)

The outline of the paper is as follows. Section 2 reviews the literature on the impact of pension wealth on consumption, savings and induced retirement. Section 3 presents a model of consumption and retirement behaviour, while the estimated models are discussed in section 4 . Section 5 concludes.

\footnotetext{
${ }^{1} \mathrm{~A}$ more eclectic model is used for retirement behaviour.
} 


\section{Review of the Literature on the Impact of Pension Wealth on Consumption, Savings and Induced Retirement}

The earliest time series studies of the effect of (state) pension wealth on consumption and savings behaviour were those of [31][32][34][36] Feldstein (1974,1976,1979, 1982). He used the life cycle model with induced retirement to identify a savings replacement (or wealth substitution) effect and a retirement effect. With the first effect, state pensions reduce the need to save privately for retirement. With the second effect, state pensions induce workers to retire earlier than they otherwise would and this increases the need to save privately for retirement in order to maintain living standards. The net effect of these two opposing influences is an empirical matter and Feldstein's own time series estimates on US data over the period 1930-74 (even when corrected for the computer programming error identified by [60]Leimer and Lesnoy (1982)) indicated that social security wealth had a small but statistically significant effect in reducing private savings (increasing consumption). He found similar results in other countries ([35]Feldstein (1980)).

Feldstein's work generated a substantial debate. One strand was theoretical and revolved around the appropriate model to test the underlying hypothesis. [4][5]Barro (1974,1978), for example, argued that Feldstein's model ignored private intergenerational transfers (such as bequests to children from parents concerned about the burden of their own retirement benefits). The effect of these would be to offset exactly the impact of mandatory social security payments, so that Ricardian equivalence holds. Barro, using a consumption function similar to Feldstein's but with additional variables (the government surplus, the unemployment rate and the stock of durable goods), found using US data that the effect of social security wealth on consumption was statistically insignificant ${ }^{2}$.

Another strand of the debate initiated by Feldstein concerned the measures that were used to proxy pension wealth. His social security wealth measure was a rather crude approximation to the underlying true variable which is the actuarial value of the social security pension that individuals expect to receive in retirement. Feldstein made the following simplifying assumptions: the ratio of benefits to disposable income remains constant over time at the historical average of 0.41 ; the number of future beneficiaries equals the number of current covered workers adjusted for differences in labour force participation by age; and the number of females receiving widow's benefits in future is proportional to the number of current male covered workers and pensioners ${ }^{3}$.

\footnotetext{
${ }^{2}$ Early UK time series studies also found that there was no statistically significant effect on savings of pension wealth whether the pension wealth measure was state pension wealth alone, occupational pension wealth alone, or state and private pension wealth combined ([49]Hemming (1978), [50]Hemming and Harvey (1983) and [17]Browning (1982)).

${ }^{3} \mathrm{UK}$ studies also made some unsatisfactory assumptions concerning pension wealth. [49]Hemming (1978) made an early attempt to use appropriate actuarial methods (discounting future anticipated cash flows weighted by survival probabilities), but his series was too short to draw meaningful conclusions and, subsequently, official estimates were revised downwards. [50]Hemming and Harvey (1983) made the following assumptions: pension wealth is a scalar multiple of current pension benefits; financial wealth is equal to the present value of an annuity determined by the current level of pre-tax interest income discounted by $10 \%$ with no allowance for real earnings growth; housing wealth is inferred from rateable values; and the possibility of being an early leaver and so getting less than the maximum pension of two thirds of final salary is ignored. [17]Browning (1982) made the following assumptions: real state pensions grow at a constant rate (less than the discount rate), even though real state pensions are constant over time, although the numbers claiming them grow over time; a rectangular age distribution over the ages 0 to 72 ; private pension wealth equals the market value of pension funds (so that the surplus is assumed always to be zero); unfunded schemes equal the size of funded schemes, so that private pension wealth is assumed to equal twice the market value of pension funds.
} 
Other investigators have found evidence inconsistent with the life cycle model's predictions that wealth built up during the working life is run down during retirement. [26]Darby (1979), [57]Kotlikoff and Summers (1981), and [59]Laitner and Juster (1996) found that 'life cycle assets' in the US (arising from accumulated savings) accounted for at most 30\% of total US assets (the remainder having been inherited). [69]Mirer (1979), [25]Danziger et al. (1983) and [52]Horioka et al. (1996) found that the elderly in the US and Japan do not decumulate wealth sufficiently rapidly (indeed they appear to accumulate wealth in the US) to be consistent with the life cycle model (under certainty with no bequest motive). [40]Friedman and Warshawsky (1990) found that the demand for annuities in retirement in the US was too low if the life cycle model with life-time uncertainty was valid. This may be because annuity yields are actuarially unfair (for both adverse selection and moral hazard reasons), so that precautionary savings are higher than would otherwise be the case in the presence of uncertain lifetimes. Involuntary bequests would be an unintended consequence of this ${ }^{4}$.

Further evidence is available from cross-section studies. Most of these found that social security wealth tends to reduce savings, while private pension wealth tends to increase savings. [56]Kotlikoff (1979) and [61]Leimer and Richardson (1992), using US data, found that social security wealth replaced between 0.6 and 0.67 of private wealth (rather than the 1 if the life cycle model was valid). [81]Takayama (1990) found that social security wealth reduces the savings ratio in Japan by $12 \%^{5}$. [44]Green (1981), using UK data, found that occupational pension savings increased discretionary non-pension savings with coefficients in the range $0.48-1.19$ (rather than -1 if there was perfect substitution).

Cross-section studies have also been used to determine the effect of pension schemes on inducing retirement. [28]Disney, Meghir and Whitehouse (1994) and [64]Meghir and Whitehouse (1997), in studies using UK data, found that workers with occupational pension rights tended to remain longer in particular jobs, but also tended to retire earlier than those without them; also the earlier the age at which workers began to accrue these rights, the more likely they were to take early retirement. The income and wealth effects of occupational pension assets therefore appear to dominate the intertemporal substitution effect which would tend to delay retirement since greater work leads to a higher final salary pension. For workers without occupational pension rights, the most likely causes of permanent job exit prior to normal retirement age are redundancy and ill-health. There are also offsetting effects present with unfunded state pension schemes, but they are rather different from those operating with funded private pension schemes. On the one hand, [77]Sheshinski (1978), [15]Boskin (1977) and [16]Boskin and Hurd (1978) argue that if higher social security taxes are needed to pay the state pensions of the growing elderly population, this provides a disincentive effect that could lead to a reduction in labour force participation and earlier retirement. On the other hand, [13]Blinder, Gordon and Wise (1980) argue that state pensions do not necessarily have the effect of encouraging

\footnotetext{
${ }^{4}$ Similar inconsistencies with the life cycle model have been found using flow rather than stock data: [82] Taylor (1971), for example, found that for the US the responsiveness of discretionary savings to a rise in social security contributions was -2.16 , when it should be -1 if Ricardian equivalence held; [83] Threadgold (1978), using UK data, found that private pension savings tended to increase total savings; [75]Pitelis (1985), also using UK data, found that the responsiveness of discretionary non-pension savings to a rise in private pension savings varied between 0.8 and 1.25 , whereas it should be -1 if there was perfect substitution between them.

${ }^{5}$ However, some studies found no significant relationship between consumption and social security wealth, e.g. [13]Blinder, Gordon and Wise (1983), [58]Kurz (1984) and [27]David and Menchik (1985), both using US data.
} 
earlier retirement, since delayed retirement after state pension age can result in a more than actuarially fair increase in the state pension. The effects differ with different social security systems, of course, and the net effect remains an empirical question for each system ${ }^{6}$.

The above review indicates three things. First, the debate over the effect of pension wealth on consumption and retirement decisions is far from being resolved. Second, there is an important need to use improved estimates of pension wealth. Third, the best modelling framework for testing the underlying hypotheses is unclear.

\section{A Model of Consumption and Retirement Behaviour}

3.1. The Consumption Function. We propose to investigate the impact of different components of wealth on consumption using [65][66] Merton's $(1969,1971)$ representative agent model. $^{7}$

The simplest version of the model, based on a HARA utility function and timeinvariant investment opportunities, gives optimal consumption as a linear function of wealth:

$$
C_{t}^{*}=a+b W_{t}
$$

where the coefficients $a$ and $b$ are, in turn, functions of the utility function, investment opportunities and, possibly, time. In the special case of a logarithmic utility function and a finite horizon $a=0$ and $b=(T-t)^{-1}$, i.e., consumption is spread evenly over the remaining lifetime, a feature that is consistent with the life cycle hypothesis. If the horizon is infinite, $a=0$ and $b=\rho$, i.e., consumption is proportional to wealth, with the constant of proportionality equal to the rate of time preference.

The Merton model has strong implications for how consumption is determined. It predicts that, apart from the parameters relating to the utility function and investment opportunities, current consumption depends only on current total wealth, not on the composition of wealth and not on any other variable ${ }^{8}$. But this is likely to hold only in a world of perfect capital and labour markets, where, for example, individuals can borrow

\footnotetext{
${ }^{6}$ The psychological research literature also offers insights. [20]Cagan (1965), for instance, identified a recognition effect in individual behaviour. When someone is obliged to join a pension scheme, they begin to recognise for the first time the importance of saving for old age and this encourages them to save even harder. Similarly, [55]Katona (1964) identified a goal-gradient effect in individual behaviour, whereby effort is heightened the nearer individuals are to their goal.

${ }^{7}$ It is well-known that the representative agent model provides a valid representation of microeconomic behaviour only under certain restrictive conditions concerning the distribution of income in the economy, namely that it is constant over time or at most a function of deterministic, time-dependent variables ([80]Stoker (1986)). However, [14]Blundell, Pashardes and Weber (1993) have shown that, once these 'aggregation factors' have been taken into account, a time-series-based representative agent model is not necessarily outperformed in terms of forecasting ability by microeconomic models involving panel data. A study by [43] Goodman, Johnson and Webb (1997, chapter 3) indicates that the distribution of income in the UK was fairly stable over the post-war period (with a gini coefficient of around 0.26) until 1985, after which inequalities (particularly at the extremes of the distribution) increased before stabilising again by 1993 (when the gini coefficient was 0.34). When a variable measuring the annual gini coefficients over the sample period was included in the equations listed in Tables 4.1 - 4.3 below, it was found to be statistically insignficant, indicating that the changes in the income distribution since 1985 were not sufficient to invalidate the representative agent model. Nevertheless, some investigators do not like the representative model in principle. Indeed, the representative agent model is a strange creature: part young, part middle aged, part old; part male, part female; part employed, part unemployed, part retired, etc.

${ }^{8}$ It also predicts that it is the levels rather than the logarithms of these variables that are important.
} 
against illiquid and non-tradeable assets such as pension wealth or human capital, and workers never experience involuntary unemployment.

In practice, we must allow for the following possibilities: that individuals do not adjust their consumption instantaneously to changes in the level of wealth; that the components of wealth may have differential effects on consumption; that other characteristics of wealth may influence consumption (e.g. actual (rather than expected) rates of return on the wealth components); that individuals are liquidity constrained; that these constraints may change over time as a result of, say, financial deregulation; and that other factors may influence consumption.

We accounted for these possibilities in the following way:

- Lagged adjustment. The estimated equations included lags to allow long-run adjustments to differ from short-run adjustments.

- Including the components of wealth as separate regressors. We decomposed personal wealth into eight categories: net financial wealth $\left(W_{F}\right)$, housing wealth $\left(W_{H}\right)$, durable wealth $\left(W_{D}\right)$, basic state pension ${ }^{9}$ wealth $\left(W_{B}\right), \operatorname{SERPS}^{10}$ wealth $\left(W_{S}\right)$, occupational pension ${ }^{11}$ wealth $\left(W_{O}\right)$, personal pension ${ }^{12}$ wealth $\left(W_{P}\right)$ and human capital $\left(W_{L}\right)$.

- Including as regressors the real returns on total wealth and its components: $r_{W}$, $r_{F}, r_{H}, r_{D}, r_{B}, r_{S}, r_{O}, r_{P}{ }^{13}$

- Liquidity constraints. The effect of liquidity constraints is to introduce current income into the consumption function: they can account for the observed 'excess sensitivity' of consumption with respect to current income that is inconsistent with the life cycle model ([45]Hall (1978), [39]Flavin (1985), [84]Zeldes (1989), [24]Cushing (1992)). Take, for example, eqn (3.1) aggregated over all consumers who are not liquidity-constrained. Liquidity-constrained individuals are restricted to consuming their current income. If such individuals receive a fraction of total personal disposable income $Y_{t}$ equal to $\lambda$, then the aggregate consumption function will take the form:

$$
C_{t}^{*}=a+b W_{t}+\lambda Y_{t}
$$

- Financial deregulation. The late 1970s and 1980s was a period of substantial financial deregulation and increasing competition between financial institutions. These forces had a major impact on personal consumption behaviour, in particular inducing a large fall in the personal savings ratio as consumers spent some of their housing equity. The effect of financial deregulation on the relaxation of liquidity

\footnotetext{
${ }^{9}$ This is a flat-rate unfunded pension available to both employees and the self-employed from state pension age (60 for women and 65 for men).

${ }^{10}$ SERPS stands for the state earnings related pension scheme: employees are automatically members of this unfunded scheme unless they have 'contracted out' into an eligible occupational or personal pension scheme.

${ }^{11}$ From a funded defined benefit scheme.

${ }^{12}$ From a funded defined contribution scheme.

${ }^{13}$ Internal rates of return were used for $r_{B}, r_{S}$, and $r_{O}$, while $r_{W}$ is the weighted average of the eight components of wealth. A constant real discount rate of $3 \%$ was used to estimate the value of human capital (the same discount rate as is used by the Government Actuary's Department to estimate the value of state pension wealth), so it is not possible to include $r_{L}$ as a separate regressor; while not entirely satisfactory, the use of a constant discount rate for human capital is nevertheless fairly common, e.g., [30]Fama and Schwert (1977), [78]Shiller (1993), and [54]Jagannathan and Wang (1994).
} 
and capital market constraints has been investigated by a number of authors, e.g. [63] Manchester and Poterba (1989), [9]Bayoumi and Koujianou (1990), [21]Campbell and Mankiw (1991), [67]Miles (1992), and [6][7]Bayoumi (1993a,b). Most of these studies concluded that liquidity constraints had an important impact on consumption in the 1970s but, by the end of the 1980s, this impact had largely vanished, except in the case of Japan. ${ }^{14}$ As a proxy for financial deregulation, [6][7]Bayoumi (1993a,b) used the ratio of total outstanding consumer credit to GDP, transformed to equal 0 in 1975 and 1 in 1988 (FINDREG) on the grounds that 'since consumer credit is used to finance deviations of consumption from income, this ratio is a useful measure of the extent to which consumers are using credit markets to smooth consumption' (Bayoumi (1993b, p.1435). ${ }^{15,16}$

- Life cycle factors. The Merton model as given in (3.1) explains the optimal consumption behaviour of a representative agent with no bequest motive. In this framework, consumption is independent of the individual's age. Different investigators have accounted for life cycle factors in a variety of ways. Some include the proportions of the population who are respectively young (the youth dependency ratio $(Y O U T H D R)$ ) and old (the elderly dependency ratio $(A G E D R)$ ) (e.g., [70]Modigliani (1970), [35]Feldstein (1980) and [68]Miles and Patel (1997)). Others include life expectancy (LIFEXP) (e.g. [46]Hamermesh (1985)). Some have attempted to discover a bequest motive. [53]Hurd (1987), for example, has tested for this using cross-section data by examining whether the savings of the elderly who have children is higher than the savings of the elderly without children. He finds no evidence for a bequest motive. However, this motive is impossible to test in an aggregate time-series context.

- Labour market status. Clearly an individual's labour market status (employed or unemployed, in work or retired) can affect consumption behaviour. A number of investigators include the unemployment rate $(U N)$. [21]Campbell and Mankiw (1991), for example, test whether the increase in unemployment in the 1980s might have tended to counteract the positive impact of financial deregulation on consumption. Alternatively, if there is a trade-off (nonseparability) between consumption and leisure, then real wages or hours worked should be included in the model, with rises in these two variables being associated with higher consumption; the unemployment rate can be used as a proxy for changes in hours worked ([4][5]Barro (1974,1978), [18]Burkhauser and Turner (1982), [8]Bayoumi (1995)). However, not everyone who is not in work is registered as unemployed. An alternative measure that can be used is the labour force participation rate $(L A B P R)$. Other investigators have included either the retirement age (e.g. [72]Munnell (1974), [23]Crawford and Lilien (1981)) or the labour force participation rate of the elderly $(A G E P R)^{17}$ ([35]Feldstein (1980)).

\footnotetext{
${ }^{14}$ This conclusion is not clearcut, however. It is not confirmed by Campbell and Mankiw who argued that 'the evolution of credit markets over the post-war period does not seem to have caused a detectable decline in $\lambda$ [in (3.2)]' (Campbell and Mankiw (1991, p.753)).

${ }^{15}$ Other measures have been used such as the index of financial deregulation developed by Muellbauer and Murphy (1993).

${ }^{16}$ For an analysis of the role of credit markets in providing consumption insurance in the presence of aggregate uncertainty, see [62] Mace (1991) and [22]Cochrane (1991).

${ }^{17}$ The weighted average percentage of women above 60 and men above 65 who are still in work.
} 
- Variables affecting portfolio decisions. Some investigators have included the variance of current income $(Y V O L)$, since uncertainty about income can reduce consumption and increase precautionary savings ([79]Skinner (1988), [19]Caballero (1990), [47]Hendry (1994)). Following [47]Hendry (1994, eqn (8)), we estimated YVOL as the absolute value of the residuals from the following regression equation:

$$
\begin{aligned}
\Delta \ln Y_{t}^{*}= & \underset{(2.52)}{0.0214}+\underset{(2.74)}{0.4731} \Delta \ln Y_{t-1}^{*}-\underset{(2.15)}{0.3117} \Delta \ln P_{t} \\
& +\underset{(1.10)}{0.1717} \Delta \ell n P_{t-1}-\underset{(2.13)}{0.2260} \ln Y D_{t-1}
\end{aligned}
$$

$\bar{R}^{2}=0.39, \mathrm{DW}=1.80$, serial correlation $\chi^{2}(1)=1.99$, functional form $\chi^{2}(1)=1.74$, normality $\chi^{2}(2)=10.58$, heteroscedasticity $\chi^{2}(1)=1.77$, where $Y^{*}$ is real income, $P$ is the price level and $\ln Y D$ is the deviation of $\ell n Y$ from a linear deterministic trend.

Others have included the inflation rate, because "nominal rather, than real interest rate payments are considered to be income in the national accounts, hence in inflationary times consumers are forced to increase saving simply to keep their debt position stable' ([7]Bayoumi (1993b, p.1434). [48]Hendry and von Ungern-Sternberg (1981) and [47]Hendry (1994) use a variable that results from multiplying the value of liquid assets by the inflation rate $\left(\dot{P}_{F}\right)$. A high value for $\dot{P}_{F}$ would be expected to induce individuals to increase their savings in order to maintain the real value of their liquid assets.

- Spillover effects from other sectors. Some investigators have included the savings of the corporate $(S C)$ and government $(S G)$ sectors since these might be substitutes for personal sector savings (complements for personal sector consumption) ([31]Feldstein (1974, who used corporate retained earnings), [4][5]Barro (1974,1978, who used the government surplus), [8]Bayoumi (1995), [68]Miles and Patel (1996)). Another possibility is to include the surplus in occupational pension schemes $(S U R$ $P L U S$ ), on the grounds that some of the surplus might be shared with pensioners, but in any event increases the wealth of the shareholders of companies running surpluses.

3.2. Retirement Behaviour. While there are still standard retirement ages (typically between 60 and 65), increasingly there is flexibility over the actual retirement age. At the same time, it is also the case that retirement is no longer a strict discrete choice variable: some people are less than fully employed prior to normal retirement age; others continue to work after this age. In addition, it is possible to induce retirement. So the retirement decision is a very complex one and is therefore very difficult to model precisely in an aggregate time series model.

We propose to investigate retirement behaviour by examining the factors influencing the labour force participation rate of the elderly $(A G E P R)$. AGEPR has been falling steadily over the sample period just as per capita wealth has been increasing. So an obvious question is to ask whether this increase in wealth has helped to induce earlier retirement. Part of the reason for $A G E P R$ falling is the inceasing longevity of the population: there are more very old people now than 50 years ago but we would expect very few of these to still be in work. To account for this we add LIFEXP to the equation. Some of the other variables that influence consumption might also influence $A G E P R$ and 
we investigate this possibility as well. The model that is estimated below is an eclectic one and not based on any particular model of optimal retirement behaviour.

\section{The Estimated Models ${ }^{18}$}

4.1. The consumption function. The most general form of the consumption function that we considered was (in real per capita terms):

$$
\begin{aligned}
C_{t}= & \alpha_{0}+\alpha_{1} C_{t-1}+\sum_{i=1}^{8} \beta_{i} W_{i t}+\sum_{i=1}^{8} \beta_{i}^{\prime} W_{i, t-1} \\
& +\sum_{i=1}^{8} \gamma_{i} r_{i t}+\sum_{i=1}^{8} \gamma_{i}^{\prime} r_{i, t-1}+\sum_{i=1}^{M} \delta_{i} Z_{i t}+\sum_{i=1}^{M} \delta_{i}^{\prime} Z_{i, t-1}+u_{t}
\end{aligned}
$$

where

$W_{i t}=i^{t h}$ component of wealth at $t$

$r_{i t}=$ real return on $i^{\text {th }}$ component of wealth at $t$

$Z_{i t}=i^{t h}$ (non-wealth) regressor out of $M$

$u_{t}=$ residual at $t$.

Eqn (4.1) is an autoregressive distributed lag (ARDL) model containing $I(1)$ variables (both endogenous and exogenous). As such it is a reparameterisation of an error correction model (ECM) and estimation methods suitable for difference-stationary variables in general need to be used. However, in the case of a model comprising either a single cointegrating vector or a recursive system (with zero correlation between the error terms), traditional methods of estimation and inference originally developed for trend-stationary variables can also be used. We show below that particular interesting cases of eqn (4.1) contain just a single cointegrating vector and that there is a recursive relationship between consumption and retirement behaviour (current consumption does not appear as a regressor in the latter equation). If we make the assumption of zero correlation between the error terms of the equations for consumption and retirement behaviour, then we can derive consistent estimates of our two-equation system using single equation methods (see [74]Pesaran and Shin (1997)). A more conventional approach would have been to use VAR estimation methods, but recent research has shown that any biases using these methods will be proportional to the dimension of the system which in our case is large (see [42] Gonzalo and Lee (1998) and [1]Abadir, Hadri and Tzavalis (1999)). Other particular cases of interest of eqn (4.1) contain two cointegrating vectors. But tests indicate that, in each case, one of these vectors has parameters that are not significantly different from those derived using least squares estimation and the other vector has an insignificant adjustment parameter, so that there is no feedback from this vector. Efficiency can therefore be improved by dropping the second vector and again using traditional methods to estimate the ARDL model incorporating just a single cointegrating vector.

We first tested for the validity of the linear version of Merton's model which says that consumption is at most a linear function of aggregate wealth. Column (1) of Table 4.1 presents estimates for the case of a logarithmic utility function and an infinite horizon. In terms of (4.1), the following restrictions are imposed: $\alpha_{0}=\alpha_{1}=\beta_{i}^{\prime}=\gamma_{i}=\gamma_{i}^{\prime}=\delta_{i}=$

\footnotetext{
${ }^{18}$ The data are annual for the UK for the period 1948-1994. Most of the wealth data in this paper are taken from Blake and Orszag (1999). The exception is human capital which is estimated as the expected present value of lifetime earnings for the whole adult population.
} 
$\delta_{i}^{\prime}=0$ and $\beta_{i}=\beta$, for all $i$. This specification of the Merton model is rejected: the estimated equation is not well-specified and in particular does not constitute a cointegrating regression; in fact the trace likelihood ratio test indicates that there are no cointegrating vectors present. Nevertheless, we derive a point estimate for the rate of time preference for the UK personal sector of $3.3 \%$. Column (2) presents the estimates for the more general case of a HARA utility function and an infinite horizon (see eqn. (3.1)), while column (3) introduces some short-term dynamics for this case. Again neither equation is well-specified: in particular the residuals are neither stationary nor serially uncorrelated. We may conclude from this that the Merton model in which current consumption depends only on current aggregate wealth is rejected by the data.

The remaining columns of Table 4.1 examine the separate effects on consumption of the eight components of aggregate wealth (i.e., allow the $\beta_{i}$ to differ). The diagnostic tests indicate that there are four cointegrating vectors. However the resulting error correction model (column (4)) is poorly specified and in particular exhibits massive predictive failure over the period 1986-94, which covered the late 80s boom and the early 90s slump. Of particular interest is the test for the equality of the coefficients on the cointegrating vectors (i.e. $\beta_{i}=\beta$, for all $i$ ). The hypothesis is decisively rejected for each of the four cointegrating vectors, only one of which (the last) has a significant adjustment parameter in the error correction model.

Table 4.2 shows the results from including additional variables as regressors in the consumption function ${ }^{19}$. Column (1) adds these extra regressors (including the total return on wealth) to the equation involving aggregate wealth. The trace likelihood ratio test indicates the presence of a just a single cointegrating vector, so that OLS provides super-consistent estimates of the parameters of this equation. The exclusion test indicates their joint significance and the equation passes all the diagnostic tests, except that for predictive failure over the period 1986-94. Column (2) adds the extra regressors to the equation involving the components of wealth, while column (3), in addition, separates the total return on wealth into its components. The trace likelihood ratio test indicates the presence of two cointegrating vectors for each of these cases. However, in each case, the test statistic reported immediately below indicates that the first of these vectors is not significantly different from that obtained from OLS estimation of the relevant restricted ARDL equation, while the second vector has a statistically insignificant adjustment parameter in the corresponding error correction model: the t-statistic is 0.92 in the case of the second cointegrating vector associated with column (2) and 0.62 in the case of the second cointegrating vector associated with column (3). Under these circumstances OLS estimation of the ARDL equations in columns (2) and (3) provide consistent estimates since the ECM term for the second cointegrating vector that is relegated to the residual term is by definition orthogonal to the included regressors. These equations also now pass all the diagnostic tests, including that for predictive failure.

Wealth has a direct net positive effect w53Tj 21. 44Aes\&s. ofld $\quad$ (ECM)T00 Td (ECM)Tj $26.6024 \quad 0$

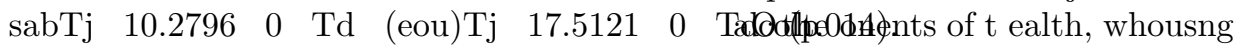


(1965). Wealth also has an indirect effect since it influences retirement behaviour (in our case measured by labour participation after normal retirement age). We find a negative relationship between consumption and $A G E P R$ which reinforces the positive direct wealth effect on consumption, since rising wealth reduces $A G E P R$ (see Table 4.4 below) and so indirectly increases consumption. The real return on aggregate wealth also has a positive impact on consumption (the marginal effect is about 0.02), indicating that the wealth effect of a change in the rate of return dominates the substitution effect. When the return on aggregate wealth is replaced by its components, only the returns on net financial wealth and basic state pension wealth are significant, again with positive coefficients.

Turning to the non-wealth variables, we find that current income is highly significant, with a coefficient varying between 0.4 and 0.7 depending on the specification: the coefficient measures the proportion of consumers who are liquidity constrained. The significance of other non-wealth variables is sensitive to the specification of the wealth variables, with only government savings $(S G)$ being significant in all three equations, and only pension fund surpluses (apart from $A G E P R$ ) being significant in both the equations using disaggregated wealth. Many variables that other investigators have found important turn out not to be significant when the wealth variable is measured correctly: durable assets, measures of financial deregulation, the age dependency ratio, life expectancy, the labour force participation rate, and income volatility. The specifications in Table 4.2 are fairly parsimonious with respect to non-wealth variables.

The results in the table can be compared with those from a study of national savings by [29]Edwards (1996) who used a panel of 36 OECD, Latin American and East Asian countries (but excluding the US and UK). His main conclusions were that private savings were negatively related to the elderly dependency ratio, government savings (with a coefficient of about -0.5), and social security spending. Our results for the UK indicate that the elderly dependency ratio is not a significant determinant of consumption or personal savings (suggesting that the shares of income consumed and saved do not change as British people get older, a result that contrasts both with the life cycle model and with Edwards' panel data evidence for other countries), that government savings partially displace personal savings (with a coefficient of about -0.2) and that social security wealth partially displaces personal savings (with a coefficient of either -0.03 or -0.3 depending on whether we use basic state pension wealth or SERPS wealth). A study by [76]Poterba et al. (1996) found that raising contribution limits for tax-exempt Individual Retirement Accounts and 401(k) pension plans in the US between 1983 and 1986 led to a one-for-one increase in personal savings. ${ }^{20}$ We find exactly the same result when personal pensions (the equivalent of IRAs and 401(k) plans) were introduced in the UK in 1988.

The results can also be compared with some cross-section studies for the UK. [2]Alessie, Devereux and Weber (1997), using a cohort analysis, while accepting that the high statutory downpayments on durables in the UK until June 1982 imposed a binding constraint on relatively young households, found that the sharp increase in consumer expenditure between 1985 and 1988 could not be explained by the additional steps towards full financial liberalisation that took place between 1984 and 1986 . We find a similar result. [3]Attanasio and Weber (1994) argued that the main cause of the consumer boom between

\footnotetext{
${ }^{20}$ However, a study by [41]Gale and Scholz (1994) covering the same period found that the increased contribution limits on IRAs merely shifted taxable forms of savings into tax-favoured IRAs with little increase overall in national savings. These two studies therefore suggest that the increase in personal savings might be substantially offset by the reduction in government savings needed to finance the tax breaks.
} 
1985 and 1986 appeared to be upward revisions in expected lifetime labour income by the younger cohorts of the population who were mainly responsible for the boom; house price increases were important determinants of consumption after 1982, but could not on their own explain the consumption surge after 1985. We also find that housing wealth is an important determinant of consumption, although we could not find a statistically significant role for human capital. $\mathrm{H} \quad 0 \quad \mathrm{Td} \quad \mathrm{Td} \quad(\mathrm{a}) \mathrm{Tj}$ 
housing wealth and personal pension wealth have the effect of delaying retirement ${ }^{23}$. The effect of income on elderly participation is strongly positive with an elasticity varying between 0.7 and 0.95 . In the equation involving aggregate wealth, an increase in youth dependency has a strong effect in delaying retirement: people have to work longer if they have more children. Interestingly, state pension wealth appears to have no net effect on the retirement decision, suggesting that for the UK, the Sheshinski, Boskin and Hurd effect and the Blinder, Gordon and Wise effect (discussed in Section 2 above) are exactly offsetting.

\footnotetext{
${ }^{23}$ This again appears to be evidence against the life cycle hypothesis.
} 
Table 4.1 Regressions of consumption on wealth

\section{Dependent variables:}

\begin{tabular}{|c|c|c|c|c|c|c|c|c|}
\hline Regressors: & $C(1)$ & $C(2)$ & $C(3)$ & $\Delta C(4)$ & [Coint & grating v & ctors] & \\
\hline $\begin{array}{l}\text { Constant } \\
\text { (t-ratio) }\end{array}$ & - & $\begin{array}{l}1.8009 \\
(24.90)\end{array}$ & $\begin{array}{l}0.7095 \\
(3.50)\end{array}$ & $\begin{array}{l}-0.3875 \\
(0.48)\end{array}$ & - & - & - & - \\
\hline$C_{-1}^{*}$ & - & - & $\begin{array}{l}0.6111 \\
(5.69)\end{array}$ & - & - & - & - & - \\
\hline$W^{*}$ & $\begin{array}{l}0.03336 \\
(56.39)\end{array}$ & $\begin{array}{l}0.0233 \\
(53.76)\end{array}$ & $\begin{array}{l}0.0094 \\
(3.83)\end{array}$ & - & - & - & - & - \\
\hline$W_{F}^{*}$ & - & - & - & - & -0.0529 & 2.8511 & 0.0638 & 0.1343 \\
\hline$W_{H}^{*}$ & - & - & - & - & 0.1433 & .8775 & .1800 & .0392 \\
\hline$W_{D}^{*}$ & - & - & - & - & 0.8941 & -8.6846 & -0.3784 & -0.7726 \\
\hline$W_{B}^{* *}$ & - & - & - & $\begin{array}{l}-0.0202 \\
(0.39)\end{array}$ & - & - & - & - \\
\hline$W_{S}^{*}$ & - & - & - & - & 3.7376 & -9.0452 & -0.5751 & 0.2399 \\
\hline$W_{O}^{*}$ & - & - & - & - & -1.0278 & 0.0260 & 0.0623 & -0.2222 \\
\hline$W_{P}^{*}$ & - & - & - & - & -1.1865 & -2.2796 & 0.8144 & -0.0076 \\
\hline$W_{L}^{*}$ & - & - & - & - & -0.0218 & 0.3802 & -0.0127 & 0.0240 \\
\hline Trend & - & - & - & $\begin{array}{l}0.0069 \\
(0.34)\end{array}$ & - & - & - & - \\
\hline $\mathrm{ECM}_{-1}$ & - & - & - & $\begin{array}{l}-0.0118 \\
(0.08)\end{array}$ & - & - & - & - \\
\hline $\mathrm{ECM}_{2}-1$ & - & - & - & $\begin{array}{l}0.1620 \\
(1.11)\end{array}$ & - & - & - & - \\
\hline $\mathrm{ECM}_{-1}$ & - & - & - & $\begin{array}{l}0.2347 \\
(1.61)\end{array}$ & - & - & - & - \\
\hline $\mathrm{ECM}_{-1}$ & - & - & - & $\begin{array}{l}0.3612 \\
(2.48)\end{array}$ & - & - & - & - \\
\hline
\end{tabular}


The Impact of Wealth on Consumption and Retirement Behaviour in the UK 14

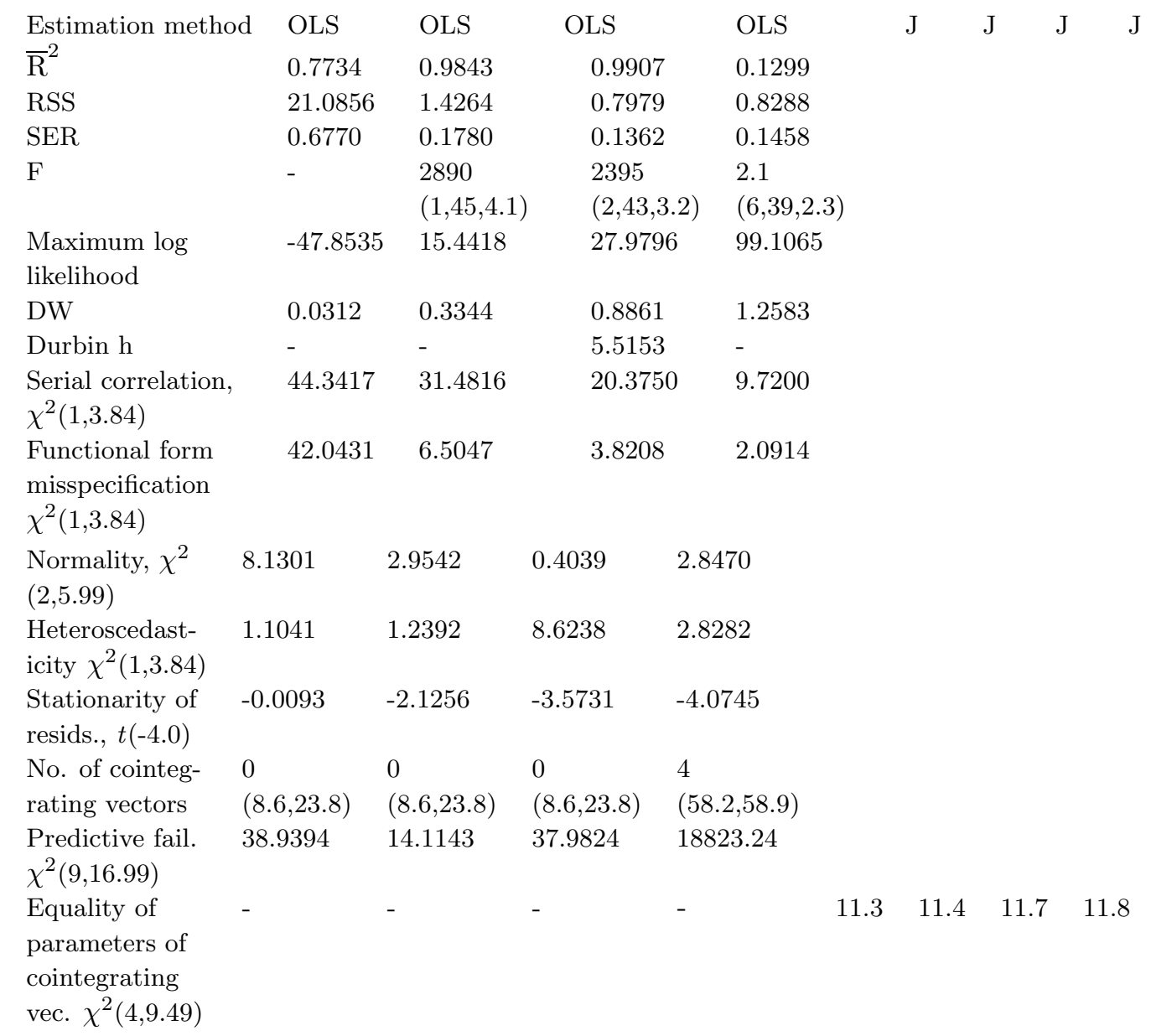

Notes:

1. Sample period: 1948 - 1994 .

2. Estimates and diagnostic tests from Microfit ([73]Pesaran and Pesaran (1997, sec 6.6$6.7)) ; \mathrm{OLS}=$ ordinary least squares; $\mathrm{J}=$ Johansen method; t-ratios in parentheses, unless otherwise indicated; first differences of variables are denoted by $\Delta$.

3. $C=$ consumption; $W=$ total wealth; $W_{F}=$ net financial wealth; $W_{H}=$ housing wealth; $W_{D}=$ durable wealth; $W_{B}=$ basic state pension wealth; $W_{S}=$ SERPS wealth; $W_{O}=$ occupational pension wealth; $W_{P}=$ personal pension wealth; $W_{L}$ $=$ human capital.

4. $\mathrm{RSS}=$ residual sum of squares;

$\mathrm{SER}=$ standard error of the regression;

$\mathrm{F}=\mathrm{F}$-test of the joint significance of the regressors;

Serial correlation = Lagrange multiplier test of residual serial correlation;

Functional form misspecification = Ramsey's RESET test using squared fitted values; 
Normality = Jarque-Bera's test based on the skewness and kurtosis of the residuals; Heteroscedasticity $=$ test of equality of error variances based on a regression of squared residuals on squared fitted values;

Stationarity of residuals = augmented Dickey-Fuller test.

5. The brackets besides the $\mathrm{F}$ and $\chi^{2}$ tests indicate the degrees of freedom and the corresponding $5 \%$ critical value.

6. *indicates $\mathrm{I}(1)$ endogenous variable, ${ }^{* *}$ indicates $\mathrm{I}(0)$ endogenous variable (about a trend), ${ }^{* * *}$ indicates $\mathrm{I}(1)$ exogenous variable, ${ }^{* * * *}$ indicates $\mathrm{I}(0)$ exogenous variable (about a trend), ECM = error correction term.

7. The test for the number of cointegrating vectors is the trace likelihood ratio test using a VAR of order 1 with unrestricted intercepts and trends (selected using the Schwarz Bayesian Criterion); beneath the figure indicating the number of cointegrating vectors is the test statistic for an additional cointegrating vector, followed by the $5 \%$ critical value for this test. The cointegrating vectors are normalised on the dependent variable.

8. The test for the parameters of a cointegrating vector being equal is based on a likelihood ratio test of over-identifying restrictions on the cointegrating vectors. Given four cointegrating vectors, there are four just-identifying restrictions and four over-identifying restrictions for this test; hence there are four degreees of freedom for the test statistic. The restrictions were imposed on each cointegrating vector in turn. 
The Impact of Wealth on Consumption and Retirement Behaviour in the UK 16

Table 4.2 Regressions of consumption on wealth and

additional variables

\begin{tabular}{|c|c|c|c|c|c|c|c|}
\hline \multirow{3}{*}{$\begin{array}{l}\text { Regressors: } \\
\text { Constant } \\
\text { (t-ratio) }\end{array}$} & \multicolumn{7}{|c|}{ Dependent variables: } \\
\hline & $C(1)$ & $C(2)$ & \multicolumn{2}{|c|}{$\begin{array}{l}\text { [Cointegrating } \\
\text { vectors] }\end{array}$} & \multirow{2}{*}{$\begin{array}{l}C(3) \\
0.5163 \\
(2.46)\end{array}$} & \multicolumn{2}{|c|}{$\begin{array}{l}\text { [Cointegrating } \\
\text { vectors] }\end{array}$} \\
\hline & $\begin{array}{l}0.3679 \\
(1.55)\end{array}$ & $\begin{array}{l}1.2693 \\
(10.24)\end{array}$ & - & - & & - & - \\
\hline$C_{-1}^{*}$ & $\begin{array}{l}0.1591 \\
(2.17)\end{array}$ & - & - & - & $\begin{array}{l}0.1295 \\
(2.31)\end{array}$ & - & - \\
\hline$W^{*}$ & $\begin{array}{l}0.0096 \\
(5.56)\end{array}$ & - & - & - & - & - & - \\
\hline$W_{H}^{*}$ & - & $\begin{array}{l}0.0417 \\
(11.18)\end{array}$ & 0.0300 & 0.0041 & $\begin{array}{l}0.0436 \\
(9.16)\end{array}$ & 0.0528 & 0.0310 \\
\hline$W_{B}^{* *}$ & - & $\begin{array}{l}0.0308 \\
(2.54)\end{array}$ & - & - & $\begin{array}{l}0.0282 \\
(2.42)\end{array}$ & - & - \\
\hline$W_{S,-1}^{*}$ & - & $\begin{array}{l}0.2901 \\
(5.58)\end{array}$ & 0.2931 & -1.0998 & $\begin{array}{l}0.2241 \\
(4.35)\end{array}$ & 0.3947 & -0.1520 \\
\hline$W_{O,-1}^{*}$ & - & $\begin{array}{l}-0.0964 \\
(4.67)\end{array}$ & -0.0352 & 0.3455 & $\begin{array}{l}-0.0934 \\
(4.59)\end{array}$ & -0.1095 & 0.0702 \\
\hline$\Delta W_{P}^{* *}$ & - & $\begin{array}{l}-1.0507 \\
(9.47)\end{array}$ & - & - & $\begin{array}{l}-0.8551 \\
(6.00)\end{array}$ & - & - \\
\hline$r_{W}^{* * * *}$ & $\begin{array}{l}0.0223 \\
(2.76)\end{array}$ & $\begin{array}{l}0.0241 \\
(4.80)\end{array}$ & - & - & - & - & - \\
\hline$r_{F}^{* * * *}$ & - & - & - & - & $\begin{array}{l}0.0016 \\
(4.25)\end{array}$ & - & - \\
\hline$r_{B}^{* * * *}$ & - & - & - & - & $\begin{array}{l}0.0507 \\
(4.32)\end{array}$ & - & - \\
\hline$Y^{*}$ & $\begin{array}{l}0.4053 \\
(7.77)\end{array}$ & $\begin{array}{l}0.7054 \\
(21.13)\end{array}$ & 0.7077 & 0.8432 & $\begin{array}{l}0.6146 \\
(12.49)\end{array}$ & 0.6601 & 0.7814 \\
\hline YOUTHDR $R^{* * *}$ & $\begin{array}{l}0.0128 \\
(1.22)\end{array}$ & - & - & - & - & - & - \\
\hline$\Delta U N^{* * * *}$ & $\begin{array}{l}-0.0533 \\
(6.68)\end{array}$ & - & - & - & - & - & - \\
\hline$A G E P R^{* * *}$ & - & $\begin{array}{l}-0.0364 \\
(4.73)\end{array}$ & 0.0119 & -0.1701 & $\begin{array}{l}-0.0324 \\
(4.32)\end{array}$ & 0.0193 & -0.0495 \\
\hline$\dot{P}_{F}^{* * *}$ & $\begin{array}{l}-0.0809 \\
(2.88)\end{array}$ & - & - & - & - & - & - \\
\hline$S G^{* * *}$ & $\begin{array}{l}0.2778 \\
(5.27)\end{array}$ & $\begin{array}{l}0.2138 \\
(5.63)\end{array}$ & 0.3208 & -0.2659 & $\begin{array}{l}0.1876 \\
(4.21)\end{array}$ & 0.1719 & -0.0002 \\
\hline$S C^{* * *}$ & - & - & - & - & $\begin{array}{l}0.1478 \\
(2.56)\end{array}$ & 0.0074 & -0.1546 \\
\hline$S U R P L U S^{* * *}$ & - & $\begin{array}{l}0.0295 \\
(2.40)\end{array}$ & -0.0071 & 0.0725 & $\begin{array}{l}0.0212 \\
(1.84)\end{array}$ & 0.0226 & 0.0350 \\
\hline
\end{tabular}




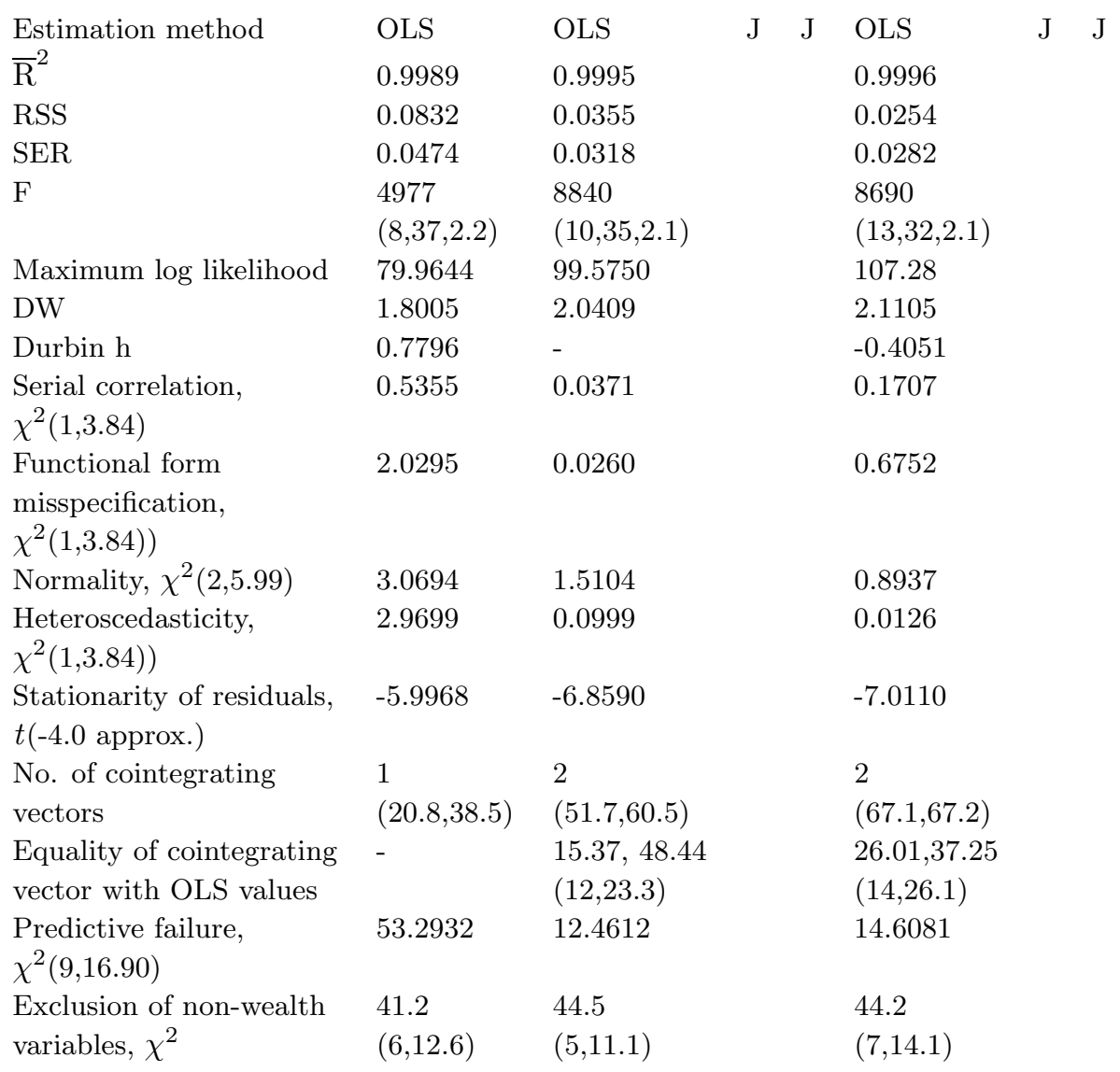

Notes:

1. See notes to Table 4.1.

2. $C=$ consumption; $W=$ total wealth; $W_{H}=$ housing wealth; $W_{B}=$ basic state pension wealth; $W_{S}=$ SERPS wealth; $W_{O}=$ occupational pension wealth; $W_{P}=$ personal pension wealth; $r_{W}=$ return on total wealth; $r_{F}=$ return on net financial wealth; $r_{B}=$ return on basic state pension wealth; $Y=$ personal disposable income; $Y O U T H D R=$ youth dependency ratio; $U N=$ unemployment rate; $A G E P R=$ age dependency ratio; $\dot{P}_{F}=$ inflation loss on liquid assets; $S C=$ company savings; $G S=$ government savings; $S U R P L U S=$ actuarial surplus in occupational pension schemes.

3. The test for the equality between the coefficients of a cointegrating vector estimated using Johansen methods and those estimated by OLS is based on a likelihood ratio test of over-identifying restrictions on each cointegrating vector. Given two cointegrating vectors, there are two just-identifying restrictions and six over-identifying restrictions for each vector in column (2) (seven overidentifying restrictions in column (3)); hence there are twelve (fourteen) degreees of freedom for the test statistic. The OLS values were imposed on each cointegrating vector in turn, while the parameters of the other vector were fixed at their unrestricted values. The test statistics 
The Impact of Wealth on Consumption and Retirement Behaviour in the UK 18

are listed in the same order as the cointegrating vectors in the adjacent columns. Beneath the test statistics are the degrees of freedom and the $2.5 \%$ critical value. 
Table 4.3 Long-run elasticities of consumption with respect to wealth and additional variables

\begin{tabular}{|c|c|c|c|}
\hline \multirow[b]{2}{*}{ Regressors: } & \multicolumn{3}{|c|}{ Dependent variable: } \\
\hline & $C(1)$ & $C(2)$ & $C(3)$ \\
\hline $\begin{array}{l}W \\
\text { (t-ratio) }\end{array}$ & $\begin{array}{l}0.3447 \\
(8.18)\end{array}$ & - & - \\
\hline$W_{H}$ & - & $\begin{array}{l}0.0712 \\
(11.18)\end{array}$ & $\begin{array}{l}0.0811 \\
(7.76)\end{array}$ \\
\hline$W_{B}$ & - & $\begin{array}{l}0.0441 \\
(2.54)\end{array}$ & $\begin{array}{l}0.0444 \\
(2.47)\end{array}$ \\
\hline$W_{S}$ & - & $\begin{array}{l}0.1066 \\
(5.58)\end{array}$ & $\begin{array}{l}0.0977 \\
(5.10)\end{array}$ \\
\hline$W_{O}$ & - & $\begin{array}{l}-0.0883 \\
(4.67)\end{array}$ & $\begin{array}{l}-0.0860 \\
(4.10)\end{array}$ \\
\hline$\Delta W_{P}$ & - & $\begin{array}{l}-0.0072 \\
(9.47)\end{array}$ & $\begin{array}{l}-0.0066 \\
(6.46)\end{array}$ \\
\hline$r_{W}$ & $\begin{array}{l}0.0054 \\
(1.04)\end{array}$ & $\begin{array}{l}0.0044 \\
(4.80)\end{array}$ & - \\
\hline$r_{F}$ & - & - & $\begin{array}{l}0.0003 \\
(3.91)\end{array}$ \\
\hline$r_{B}$ & - & - & $\begin{array}{l}0.0063 \\
(2.33)\end{array}$ \\
\hline$Y$ & $\begin{array}{l}0.5030 \\
(9.78)\end{array}$ & $\begin{array}{l}0.7727 \\
(21.13)\end{array}$ & $\begin{array}{l}0.7693 \\
(20.58)\end{array}$ \\
\hline YOUTHDR & $\begin{array}{l}0.0528 \\
(1.19)\end{array}$ & - & - \\
\hline$\Delta U N$ & $\begin{array}{l}-0.0015 \\
(5.11)\end{array}$ & - & - \\
\hline$A G E P R^{*}$ & - & $\begin{array}{l}-0.0819 \\
(4.73)\end{array}$ & $\begin{array}{l}-0.0702 \\
(3.64)\end{array}$ \\
\hline$\dot{P}_{F}$ & $\begin{array}{l}-0.0068 \\
(2.21)\end{array}$ & - & - \\
\hline$S G$ & $\begin{array}{l}0.0035 \\
(8.32)\end{array}$ & $\begin{array}{l}0.0021 \\
(5.63)\end{array}$ & $\begin{array}{l}0.0023 \\
(5.41)\end{array}$ \\
\hline$S C$ & - & - & $\begin{array}{l}0.0180 \\
(2.02)\end{array}$ \\
\hline SURPLUS & - & $\begin{array}{l}0.0018 \\
(2.40)\end{array}$ & $\begin{array}{l}0.0013 \\
(1.68)\end{array}$ \\
\hline
\end{tabular}

Notes:

1. See notes to Table 4.1 and note 2 of Table 4.2 .

2. The elasticities are evaluated at the sample means. 
The Impact of Wealth on Consumption and Retirement Behaviour in the UK 20

Table 4.4 Regression of the age participation rate on wealth and other variables

\begin{tabular}{|c|c|c|}
\hline Regressors: & $\begin{array}{l}\text { Dependent } \\
A G E P R(1)\end{array}$ & $\begin{array}{l}\text { variable: } \\
A G E P R(2)\end{array}$ \\
\hline $\begin{array}{l}\text { Constant } \\
\text { (t-ratio) }\end{array}$ & $\begin{array}{l}122.2589 \\
(5.38)\end{array}$ & $\begin{array}{l}5.8181 \\
(3.78)\end{array}$ \\
\hline$A G E P R_{-1}^{* * *}$ & $\begin{array}{l}0.5614 \\
(5.21)\end{array}$ & $\begin{array}{l}0.5541 \\
(5.23)\end{array}$ \\
\hline$W^{*}$ & $\begin{array}{l}-0.0346 \\
(2.64)\end{array}$ & - \\
\hline$W_{H}^{*}$ & - & $\begin{array}{l}0.1881 \\
(4.87)\end{array}$ \\
\hline$W_{O}^{*}$ & - & $\begin{array}{l}-0.5350 \\
(3.77)\end{array}$ \\
\hline$W_{P}^{*}$ & - & $\begin{array}{l}2.3037 \\
(4.94)\end{array}$ \\
\hline$W_{L}^{*}$ & - & $\begin{array}{l}-0.0586 \\
(4.92)\end{array}$ \\
\hline$Y^{*}$ & $\begin{array}{l}1.9581 \\
(3.63)\end{array}$ & $\begin{array}{l}1.2056 \\
(4.35)\end{array}$ \\
\hline YOUTHDR $R^{* * *}$ & $\begin{array}{l}0.4598 \\
(2.97)\end{array}$ & - \\
\hline$L I F E X P^{* * * *}$ & $\begin{array}{l}-1.6722 \\
(5.47)\end{array}$ & - \\
\hline Estimation method & OLS & OLS \\
\hline$\overline{\mathrm{R}}^{2}$ & 0.9824 & 0.9855 \\
\hline RSS & 6.8758 & 5.5158 \\
\hline SER & 0.4146 & 0.3761 \\
\hline Mean & 12.3213 & 12.3213 \\
\hline $\mathrm{SD}$ & 3.1226 & 3.1226 \\
\hline $\mathrm{F}$ & $\begin{array}{l}503 \\
(5,40,2.5)\end{array}$ & $\begin{array}{l}511 \\
(6,39,2.3)\end{array}$ \\
\hline Maximum log likelihood & -21.5567 & -16.4874 \\
\hline DW & 1.9476 & 2.1090 \\
\hline Durbin h & 0.2602 & -0.5317 \\
\hline $\begin{array}{l}\text { Serial correlation, } \\
\chi^{2}(1,3.84)\end{array}$ & 0.0074 & 0.2615 \\
\hline $\begin{array}{l}\text { Functional form } \\
\text { misspecification, } \chi^{2}(1.3 .84)\end{array}$ & 0.3085 & 7.9855 \\
\hline
\end{tabular}


The Impact of Wealth on Consumption and Retirement Behaviour in the UK 21

$\begin{array}{lll}\text { Normality, } \chi^{2}(2,5.99) & 0.6170 & 0.6866 \\ \begin{array}{l}\text { Heteroscedasticity, } \\ \chi^{2}(1,3.84)\end{array} & 1.0389 & 3.6756 \\ \begin{array}{l}\text { Stationarity of } \\ \text { residuals, t(-5.0 approx.) }\end{array} & -6.6313 & -7.0162 \\ \begin{array}{l}\text { No. of cointegrating } \\ \text { vectors }\end{array} & 1 & 1 \\ \begin{array}{l}\text { Predictive failure, } \\ \chi^{2}(9,16.90)\end{array} & (29.4,39.3) & (67.2,82.2) \\ & 6.2297 & 11.9268\end{array}$

Note:

1. See notes to Table 4.1 .

2. $A G E P R=$ age dependency ratio; $W=$ total wealth; $W_{H}=$ housing wealth; $W_{O}=$ occupational pension wealth; $W_{P}=$ personal pension wealth; $W_{L}=$ human capital; $Y=$ personal disposable income; YOUTHDR= youth dependency ratio; $L I F E X P$ $=$ life expectancy. 
The Impact of Wealth on Consumption and Retirement Behaviour in the UK 22

Table 4.5 Long-run elasticities of the age participation rate on wealth and other variables

\begin{tabular}{lll} 
& \multicolumn{2}{c}{ Dependent variable: } \\
Regressors: & $A G E P R(1)$ & $A G E P R(2)$ \\
& & \\
$W$ & -0.4413 & \\
& $(1.53)$ & \\
$W_{H}$ & - & 0.1534 \\
& & $(3.89)$ \\
$W_{O}$ & - & -0.4839 \\
& & $(14.50)$ \\
$W_{P}$ & - & 0.0682 \\
& & $(10.17)$ \\
$W_{L}$ & & -0.5148 \\
& - & $(3.09)$ \\
$Y$ & & 0.7058 \\
$Y O U T H D R$ & 0.9520 & $(4.11)$ \\
& $(2.17)$ & - \\
LIFEXP & 2.0485 & \\
& $(10.81)$ & -
\end{tabular}

Notes:

1. See notes to Table 4.1 and note 2 of Table 4.4 .

2. The elasticities are evaluated at the sample means. 


\section{CONClusion}

Economic theory suggests that the most suitable functional form for consumption is as a linear function of wealth. Capital and labour market imperfections may mean that the components of wealth have differential effects and that other variables such as those relating to income, labour market or demographic status and spillovers from other sectors also have important influences. Further, wealth can influence the retirement decision which, in turn, can affect consumption.

We find that all these factors are important in our analysis of consumption and retirement behaviour in the UK. In particular, we find that, when wealth is measured correctly to include pension wealth, housing wealth and human capital, we can derive relatively parsimonious models explaining both aggregate consumption and labour market participation by the elderly. These models forecast well between 1986 and 1994, a period for which conventional (mainly logarithmic) consumption functions have forecasted badly.

In terms of state pension wealth, we find similar results to those found by [31] [32] [34] [36] Feldstein $(1974,1976,1979,1982)$, namely that state pensions have a strong savings replacement effect and reduce the need to save privately for retirement. However, they have no induced retirement effect (or at least an effect in reducing the elderly participation rate). Private occupational pensions, in contrast, have a direct effect in increasing savings (reducing consumption), but an indirect effect in lowering savings via their effect on lowering the elderly participation rate (which helps to raise consumption). The net effect on savings is positive, however. Private personal pensions also have a direct effect in increasing savings, and this is reinforced by the positive effect that personal pensions have in raising the elderly participation rate. ${ }^{24}$ In addition, we found that occupational pension fund surpluses had an effect in raising consumption (as a result of contribution holidays). So one possible explanation for conventional UK consumption functions underpredicting the consumer boom in the late 1980s is that they ignore pension wealth, especially state pension (SERPS) wealth and the occupational pension fund surpluses that arose from the stock market boom of the 1980s.

We draw three conclusions from this study. First, our results differ markedly from those found from other UK time series studies that have tested the impact of pension wealth on consumption: we put the fact that these studies found no significant effect down to their poor measures of pension wealth. Second, the results from this time series study are broadly consistent with those from cross-section studies: for example, both types of study indicate that social security and housing wealth reduce personal savings, that private pension wealth increases personal savings, that occupational pensions help to induce retirement, and that personal pensions tend to delay retirement. Third, our results do not appear to be consistent with the life cycle hypothesis: for example, we do not find that the share of income saved falls as people get older.

Certain important policy implications also emerge from this study. First, if governments wish to increase national savings or delay retirement, they should consider establishing individual retirement accounts for state pension schemes. This has been recommended by, inter alia, [33][37]Feldstein $(1978,1997) .{ }^{25}$ Second, as capital market imperfections are

\footnotetext{
${ }^{24}$ From Tables 4.4 and 4.8 , the long-run elasticities of savings with respect to occupational and personal pension wealth, taking into account their long-run impact on the elderly participation rate, are 0.0577 and 0.0127 respectively.

${ }^{25}$ National savings increased sharply in Chile following the privatisation of pension provision in 1981 ([43]Holzman (1997)), although, as [41]Gale and Scholz (1994) have shown, any tax breaks used to encourage private pensions will tend to reduce public savings. [38]Feldstein and Bacchetta (1991) have also shown that policies that raise domestic savings also succeed in raising the domestic capital stock: at
} 
increasingly eliminated, consumers will find that they can borrow against their 'illiquid' pension assets in the same way that they found they could borrow against their "illiquid' housing assets from the beginning of the 1980s. This will have a striking impact on consumption and make it much more difficult for the authorities to influence consumption using conventional policy tools. It could even offset the positive savings effect from private, funded pension schemes.

\section{DATA APPENDix}

Some of the data used in this study were taken from publicly available sources; other data needed to be constructed. Table 6.1 lists definitions and sources. All the level variables are measured in real per capita terms, while the rates of return are in real terms. The data are annual.

The wealth variables and the rates of return on these needed to be constructed. We used eight categories of personal wealth: net financial wealth, housing wealth, consumer durable assets, basic state pension wealth, state earnings related pension scheme (SERPS) wealth, occupational pension wealth, personal pension wealth, and human capital. The construction of the first seven categories was undertaken in [11]Blake and Orszag (1999) and the data for these variables are taken directly from this source. Human capital is estimated as the expected present value of lifetime earnings (that is, earnings both in work and retirement) for the whole adult population (assuming a constant real discount rate of 3\%, the same as that used by the Government Actuary's Department in preparing estimates of state and occupational pension benefits in the UK).

The definitions of the rates of return are also given in Table 6.1. The expected rate of return from membership of a defined benefit pension scheme has to take into account the fact that while current pension contributions buy current accrued pension rights, the actual pension benefit does not take place until retirement. The means that accrued benefits have to be revalued and survived to retirement age, dynamised from retirement age until death and then discounted back to the date of accrual in order to find the internal rate of return on the scheme.

Contributions $\left(K_{t}\right)$ into a defined benefit scheme are usually proportional to current income and in the case of occupational schemes attract tax relief:

$$
K_{t}=\gamma_{t}\left(1-\tau_{1}\right) Y_{t}
$$

where

$$
\begin{aligned}
\gamma_{t} & =\text { member's contribution rate } \\
Y_{t} & =\text { member's current income } \\
\tau_{1} & =\text { marginal tax rate in work. }
\end{aligned}
$$

These contributions buy an accrued benefit $\left(B_{t}\right)$ which is generally related to salary at retirement and is taxable. Define:

$$
B_{t}=\beta_{t}\left(1-\tau_{2}\right) Y_{t}\left(\frac{\left(1+g_{p}\right)\left(1+g_{Y}\right)}{1+k}\right)^{M}\left[\sum_{s=0}^{L}\left(\frac{1+g_{p}}{1+k}\right)^{s}+\lambda \sum_{s=0}^{L^{\prime}}\left(\frac{1+g_{p}}{1+k}\right)^{s+L+1}\right]
$$

most one-third of any increment leaks abroad. 


$$
=\frac{\beta_{t}\left(1-\tau_{2}\right)\left(1+g_{Y}\right)^{M}\left[\left(1-v^{L}\right)(1+r)^{L}+\lambda\left(1-v^{L^{\prime}}\right)\right]}{\delta(1+r)^{M+L}} Y_{t}
$$

where

$\beta_{t}=$ annual pension accrual rate (e.g. $\left.1 / 60^{\text {th }}\right)$

$\tau_{2}=$ marginal tax rate in retirement

$g_{p}=$ forecast inflation rate (we assume this equals the actual inflation rate in year $t$; similar results were obtained using a five-year moving average of inflation)

$g_{Y}=$ assumed growth rate in labour productivity $(=1.5 \%)$

$M=$ number of years to normal retirement

$L=$ expected pension length of member

$L^{\prime}=$ additional expected pension length of surviving spouse

$\lambda=$ pension fraction of surviving spouse (e.g. 0.5)

$r=\frac{1+k}{1+g_{p}}-1=$ real interest rate

$v=\frac{1}{1+r}$

$\delta=\ell n(1+r)=$ force of (real) interest.

The expected nominal return from scheme membership is the discount rate $k$ that equates the present values of benefits in (6.2) and current contributions in (6.1) (i.e. the internal rate of return).

We can calculate the internal rates of return on the three defined benefit schemes for the average scheme member who in the case of the state scheme is 41 years old with 21 years to retirement $(M=21)$ and in the case of an occupational scheme is 43 years old with 19 years to retirement $(M=19)$. We note that the rate of return will not depend on the member's current income, $Y_{t}$. It will also not depend on the tax rate so long as contributions are tax relieved and the pension is taxed at the same rate as contributions are relieved (i.e. $\tau_{1}=\tau_{2}$ ): a pension scheme gives a tax subsidy during the contribution phase but (with the exception of the tax-free lump sum) takes it back during the benefit phase. However, the state pension schemes do not give tax relief on contributions, yet the pension is taxable, so there might be a tax effect with these schemes. Also if the marginal tax rate is lower in retirement than in work, this will generate a tax effect, since the pension scheme then permits tax avoidance rather than simply tax deferral. The rate of return will depend positively on the accrual rate, the growth rate in labour productivity, the assumed inflation rate and on longevity; it will be negatively related to the contribution rate.

The pension length differs according to the type of scheme: occupational pension scheme members tend to experience lighter mortality than the population as a whole and so will tend to draw their pensions for longer. The estimated pension lengths in the state schemes were based on commonly-used mortality tables covering the whole population, namely English Life Tables No.11 (1950-52), No.12 (1960-62), No.13 (1970-72), and No.14 
(1980-82), with interpolation for intervening years. We took the case of a 'hybrid' 41-yearold male with a 36-year-old spouse. For example in 1981, such a man could expect to live until he was 73 years and his wife could expect to live until she was 79 . If this man retired at 62 (i.e. half way between the state retirement age for men and women), his pension length would be 11 years and the surviving spouse's pension length would be 6 years. In contrast, with occupational schemes, the estimated pension lengths were based on the Institute and Faculty of Actuaries' tables a(55) and a(90) for annuitants, again with interpolation for intervening years; the expected life time of an annuitant equals the value of a life-time annuity of one unit when the interest rate is zero. These tables indicate that occupational pension scheme members and their spouses live about five years longer than for the population as a whole.

In the case of the basic state pension scheme, the contribution rate $\left(\gamma_{t}\right)$ is $2 \%$ of the LEL. There is no tax relief on contributions into the BSP scheme and although the BSP is taxable, its annual value is below the single individual's personal allowance, so we can ignore tax effects here. In terms of eqn. (6.1), $Y_{t}=L E L_{t}$ and $\tau_{1}=0$. The average annual accrual rate $\left(\beta_{t}\right)$ is $2.42 \%$ (i.e. the average of the male and female accrual rates of $1 / 44^{\text {th }}$ and $1 / 39^{\text {th }}$ respectively).

In the case of SERPS, there is no tax relief on contributions made by the employee, but the SERPS pension is taxable and the average person is likely to pay tax on it once the BSP has been taken into account. The annual pension accrual rate has been falling over time:

$\begin{array}{ll}1978-87 & 1.25 \% \\ 1988 & 1.225 \\ 1989 & 1.205 \\ 1990 & 1.188 \\ 1991 & 1.173 \\ 1992 & 1.161 \\ 1993 & 1.150 \\ 1994 & 1.141\end{array}$

The GAD surveys of occupational pension schemes found the following gross average member's contribution rates into such schemes has been rising over time:

$\begin{array}{ll}1956 & 3.34 \% \\ 1963 & 3.50 \\ 1967 & 3.60 \\ 1971 & 3.70 \\ 1973 & 4.08 \\ 1975 & 4.29 \\ 1983 & 4.64 \\ 1987 & 4.72 \\ 1991 & 4.67\end{array}$

We used interpolation for the intervening years. The average annual accrual rate is $1.67 \%$ (i.e. $1 / 60^{\text {th }}$ ). Most people commute part of their pension into a tax-free lump sum of 1.50 times their final salary and receive a reduced pension based on the $80^{\text {ths }}$ scale (i.e. $1.25 \%$ ) but this equates to an accrual rate of approximately $1.67 \%$. 
Personal pension schemes are defined contribution schemes and the value of the pension depends exclusively on the size of the contributions and the subsequent investment performance. The minimum net contribution rate into an appropriate personal pension scheme is equal to the contracted out rebate as follows:

$\begin{array}{ll}1987 & 2.5 \% \\ 1988-92 & 2.0 \\ 1993+ & 1.8\end{array}$

The GAD's 1991 survey of occupational pension schemes (Table 6.5) showed that the average member's contribution into a money purchase scheme was higher than the minimum at $4.95 \%$. The rate of return on personal pension scheme assets is defined by:

$$
k_{P t}=\frac{K_{t}\left(1-c_{t}^{m}\right)+W_{P t}\left(1-c^{f}\right)}{K_{t}\left(1-\tau_{1}\right)+W_{P t}}\left(1+k_{t}\right)-1
$$

where

$K_{t}=$ contribution amount into personal pension scheme

$W_{P t}=$ value of accrued personal pension assets

$c_{t}^{m}=$ rate of management charges on contributions

$c^{f}=$ rate of fund management charges (we assume 1 per cent)

$k_{t}=$ total (nominal) rate of return on financial assets.

The data for eqn. (6.3) are taken from Table 12 of [11]Blake and Orszag (1999).

The rates of return used in the analysis are listed in Table 6.2. Table 6.3 shows the means and standard deviations of the variables used in the analysis. It also shows that most of the variables contain unit roots. However, LIFEXP, YVOL and most of the rates of returns are stationary.

Figs. 6.1-6.6 show graphs of some of the data used in the analysis. Fig. 6.1 shows the well-known strong positive relationship between consumption expenditure and personal disposable income over the period 1948 to 1994 . Fig. 6.2 shows that net financial wealth was fairly static during the 1950 s and $60 \mathrm{~s}$, but fell sharply as a result of the high inflation of the 1970s and then rose sharply as a result of the stock market boom of the 1980s and 90s. Housing wealth has risen sharply over the period, but has been subject to three significant booms and slumps since 1970. Figs. 6.3 and 6.4 show how state and private pension wealth have grown steadily over the period. Fig. 6.5 shows how significantly the weighting of human capital $\left(W_{L}\right)$ is in aggregate wealth. Finally Fig. 6.6 shows that the elderly participation rate has been falling over most of the period, but appears to have stabilised in the 1980s. 
Table 6.1 Data definitions and sources

Symbol Name

$Y$

C

W

$W_{F} \quad$ Net financial

$W_{H} \quad$ Housing wealth ${ }^{1}$

$W_{D} \quad$ Durable assets ${ }^{1}$

$W_{B}$ wealth $^{1}$

Personal disposable income $^{1,2}$

Consumers

expenditure $^{1,2}$

Wealth $^{1}$

Basic state pension wealth $^{1}$

\section{Definition}

Total personal income before tax gross income of employees (including employers' National Insurance contributions and employers' contributions to private sector pension schemes) plus the gross income of the selfemployed plus gross rental income plus net investment income (total interest receipts minus total interest paid)] minus tax payments on income, employee and employer National Insurance contributions, council tax, and other current transfers (£'000 (1990) per capita)

Total consumers expenditure on goods and services (£'000 (1990) per capita)

Total personal wealth (£'000 (1990) per capita)

Gross personal financial assets minus gross personal financial liabilities (£'000 (1990) per capita)

Value of housing stock (£'000 (1990) per capita)

Value of personal holdings of durable assets (£’000 (1990) per capita)

Value of accrued rights in the basic state pension scheme (£'000 (1990) per capita)

\section{Source}

Economic

Trends

Annual

Supplement

Economic

Trends

Annual

Supplement

Blake and

Orszag (1999)

Blake and

Orszag (1999)

Blake and

Orszag (1999)

Blake and

Orszag (1999)

Blake and Orszag (1999) 


\begin{tabular}{|c|c|c|c|}
\hline$W_{S}$ & $\begin{array}{l}\text { SERPS pension } \\
\text { wealth }^{1}\end{array}$ & $\begin{array}{l}\text { Value of accrued rights in the } \\
\text { State Earnings Related Pension } \\
\text { Scheme (£'000 (1990) per capita) }\end{array}$ & $\begin{array}{l}\text { Blake and } \\
\text { Orszag (1999) }\end{array}$ \\
\hline$W_{O}$ & $\begin{array}{l}\text { Occupational } \\
\text { pension wealth }^{1}\end{array}$ & $\begin{array}{l}\text { Value of accrued rights in } \\
\text { occupational pension schemes } \\
\text { (£'000 (1990) per capita) }\end{array}$ & $\begin{array}{l}\text { Blake and } \\
\text { Orszag (1999) }\end{array}$ \\
\hline$W_{P}$ & $\begin{array}{l}\text { Personal pension } \\
\text { wealth }^{1}\end{array}$ & $\begin{array}{l}\text { Value of assets in personal pension } \\
\text { schemes (£'000 (1990) per capita) }\end{array}$ & $\begin{array}{l}\text { Blake and } \\
\text { Orszag (1999) }\end{array}$ \\
\hline$W_{L}$ & Human capital ${ }^{1}$ & $\begin{array}{l}\text { Expected present value of lifetime } \\
\text { earnings (£'000 (1990) per capita) }\end{array}$ & \\
\hline$r_{F}$ & $\begin{array}{l}\text { Return on net } \\
\text { financial wealth }\end{array}$ & $\begin{array}{l}\text { Weighted rate of return on gross } \\
\text { personal financial assets minus } \\
\text { weighted rate of interest on gross } \\
\text { personal financial liabilities ( } \% \text { real) }\end{array}$ & \\
\hline$r_{H}$ & $\begin{array}{l}\text { Return on } \\
\text { housing wealth }\end{array}$ & $\begin{array}{l}\text { Capital gains plus rental yield } \\
(=\text { consol yield) minus depreciation } \\
\text { on housing wealth }(=1 \%) \text { ( } \% \text { real })\end{array}$ & \\
\hline$r_{D}$ & $\begin{array}{l}\text { Return on } \\
\text { durable assets }\end{array}$ & $\begin{array}{l}\text { Minus depreciation on durable } \\
\text { assets }(=10 \%) \text { ( } \% \text { real })\end{array}$ & \\
\hline$r_{B}$ & $\begin{array}{l}\text { Return on basic } \\
\text { state pension } \\
\text { wealth }^{3}\end{array}$ & $\begin{array}{l}\text { Internal rate of return on members' } \\
\text { contributions into the basic state } \\
\text { pension scheme ( } \% \text { real) }\end{array}$ & $\begin{array}{l}\text { Eqns }(6.1) \\
\text { and }(6.2)\end{array}$ \\
\hline$r_{S}$ & $\begin{array}{l}\text { Return on } \\
\text { SERPS wealth }^{3}\end{array}$ & $\begin{array}{l}\text { Internal rate of return on members' } \\
\text { contributions into SERPS (\% real) }\end{array}$ & $\begin{array}{l}\text { Eqns }(6.1) \\
\text { and }(6.2)\end{array}$ \\
\hline$r_{O}$ & $\begin{array}{l}\text { Return on } \\
\text { occupational } \\
\text { pension wealth }\end{array}$ & $\begin{array}{l}\text { Internal rate of return on members' } \\
\text { contributions into occupational } \\
\text { pension schemes ( } \% \text { real) }\end{array}$ & $\begin{array}{l}\text { Eqns. }(6.1) \\
\text { and }(6.2)\end{array}$ \\
\hline$r_{P}$ & $\begin{array}{l}\text { Return on } \\
\text { personal } \\
\text { pension wealth }\end{array}$ & $\begin{array}{l}\text { Return on assets in personal pension } \\
\text { schemes (\% real) }\end{array}$ & Eqn. (6.3) \\
\hline$r_{W}$ & $\begin{array}{l}\text { Return on total } \\
\text { wealth }\end{array}$ & $\begin{array}{l}\text { Weighted-average return on } \\
\text { eight categories of wealth }\end{array}$ & \\
\hline
\end{tabular}


The Impact of Wealth on Consumption and Retirement Behaviour in the UK 30

\begin{tabular}{|c|c|c|c|}
\hline$Y V O L$ & $\begin{array}{l}\text { Income } \\
\text { volatility }\end{array}$ & $\begin{array}{l}\text { Absolute value of residuals from } \\
\text { regression equation for } \mathrm{Y}(\%)\end{array}$ & $\begin{array}{l}\text { Hendry (1994, } \\
\text { Eqn. (8)) }\end{array}$ \\
\hline$\dot{P}_{F}$ & $\begin{array}{l}\text { Inflation loss on } \\
\text { liquid assets }\end{array}$ & $\begin{array}{l}\text { Product of retail price inflation } \\
\text { rate and WF (£'000 (1990) per } \\
\text { capita) }\end{array}$ & \\
\hline FINDREG & $\begin{array}{l}\text { Index of financial } \\
\text { deregulation }\end{array}$ & $\begin{array}{l}\text { Ratio of outstanding consumer } \\
\text { credit to GDP between } 1975 \\
\text { and } 1988 \text { transformed to equal } \\
0 \text { in } 1975 \text { and } 1 \text { in } 1988 ; 0 \text { for } \\
\text { other years }\end{array}$ & $\begin{array}{l}\text { Annual } \\
\text { Abstract of } \\
\text { Statistics }\end{array}$ \\
\hline YOUTHDR & $\begin{array}{l}\text { Youth depend- } \\
\text { ency ratio }\end{array}$ & $\begin{array}{l}\text { Population aged below } 15 \text { as } \\
\text { a percentage of the total } \\
\text { population }(\%)\end{array}$ & $\begin{array}{l}\text { Government } \\
\text { Actuary's } \\
\text { Department }\end{array}$ \\
\hline$A G E D R$ & $\begin{array}{l}\text { Age dependency } \\
\text { ratio }\end{array}$ & $\begin{array}{l}\text { Population aged above } 60 \text { as } \\
\text { a percentage of the total } \\
\text { population }(\%)\end{array}$ & $\begin{array}{l}\text { Government } \\
\text { Actuary's } \\
\text { Department }\end{array}$ \\
\hline LIFEXP & $\begin{array}{l}\text { Life } \\
\text { expectancy }\end{array}$ & Average age at death (years) & $\begin{array}{l}\text { English life } \\
\text { Tables, } \\
\text { Office of } \\
\text { Population, } \\
\text { Censuses and }\end{array}$ \\
\hline$U N$ & $\begin{array}{l}\text { Unemployment } \\
\text { rate }\end{array}$ & $\begin{array}{l}\text { Total unemployment as a } \\
\text { percentage of the total } \\
\text { workforce }^{4}(\%)\end{array}$ & $\begin{array}{l}\text { Economic Trends } \\
\text { Annual } \\
\text { Supplement }\end{array}$ \\
\hline$L A B P R$ & $\begin{array}{l}\text { Labour force } \\
\text { participation } \\
\text { rate }\end{array}$ & $\begin{array}{l}\text { Workforce in employment }{ }^{5} \text { as } \\
\text { a percentage of the population } \\
\text { aged between } 15 \text { and } 60(\%)\end{array}$ & $\begin{array}{l}\text { Economic Trends } \\
\text { Annual } \\
\text { Supplement }\end{array}$ \\
\hline$A G E P R$ & $\begin{array}{l}\text { Elderly } \\
\text { participation } \\
\text { rate }\end{array}$ & $\begin{array}{l}\text { Economically active males } \\
(\geq 65) \text { plus females }(\geq 60) \text { as } \\
\text { a percentage of the population } \\
\text { of males }(\geq 65) \text { plus females } \\
(\geq 60)(\%)\end{array}$ & $\begin{array}{l}\text { British Labour } \\
\text { Statistics Historical } \\
\text { Abstract 1886- } \\
1968 \text { (Table 109), } \\
\text { General Household } \\
\text { Survey } 1993 \\
\text { (Table 5.3), Labour } \\
\text { Market Trends, } \\
\text { Office for } \\
\text { National Statistics } \\
\text { (Table 7.3, July } \\
\text { 1997) Surveys }\end{array}$ \\
\hline
\end{tabular}


$S C$

$$
\begin{aligned}
& \text { Company } \\
& \text { savings }{ }^{1}
\end{aligned}
$$

$S G$

Government
savings ${ }^{1}$

SURPLUS

Actuarial
surplus in
occupational
pension
schemes $^{1}$

Financial surplus of companies

plus gross domestic fixed

capital formation minus (net)

capital transfers (£'000

(1990) per capita)

Financial surplus of government plus gross domestic fixed

capital formation minus (net)

capital transfers (£'000

(1990) per capita)

Market value of pension assets

minus value of accrued

rights in occupational pension

schemes (£'000 (1990) per

capita)
Annual Abstract

of Statistics

Economic Trends

Annual Supplement, British Economy

Key Statistics 1900-1970

Notes:

1. This variable is measured in real per capita terms. The nominal variable (in £bn, current prices) is divided by $P \times P O P$, where $P$ is the index of retail prices (1990 $=1$ ) and $P O P$ is the population aged 15 or above (in millions)).

2. Personal savings is defined as: personal disposable income minus consumers expenditure on goods and services. This implies that contributions to the state pension schemes, because they are financed on a pay-as-you-go basis, are not part of aggregate personal savings (they are treated as transfers from current workers to current pensioners), but contributions to private funded pension schemes are part of aggregate personal savings.

3. This variable is a real rate of interest expressed in the form $\ln \left((1+k) /\left(1+g_{p}\right)\right)$ where $k$ is the nominal return and $g_{p}$ is the inflation rate $\left(\ln \left(P / P_{-1}\right)\right)$.

4. The total workforce is defined as the sum of the workforce in employment and the unemployed.

5. The workforce in employment is defined as the sum of employees in employment, the self-employed, those in work-related government training programmes and those serving in HM Armed Forces. 
The Impact of Wealth on Consumption and Retirement Behaviour in the UK 32

Table 6.2 Rates of return on seven categories of personal wealth 1948-94 (Nominal, percent per annum)

\begin{tabular}{|c|c|c|c|c|c|c|c|}
\hline Year & $r_{F}$ & $r_{H}$ & $r_{D}$ & $r_{B}$ & $r_{S}$ & $r_{O}$ & $r_{P}$ \\
\hline 1948 & -0.6 & 14.8 & -12.9 & 15.3 & - & 13.7 & - \\
\hline 1949 & -2.7 & -1.8 & -14.2 & 15.0 & - & 13.6 & - \\
\hline 1950 & 4.9 & 5.6 & -12.7 & 15.2 & - & 14.0 & - \\
\hline 1951 & 1.8 & 9.1 & -27.1 & 20.6 & - & 18.4 & - \\
\hline 1952 & -0.6 & -1.1 & -12.3 & 20.6 & - & 16.5 & - \\
\hline 1953 & 10.6 & -4.6 & -7.8 & 15.1 & - & 15.1 & - \\
\hline 1954 & 19.8 & -1.6 & -10.0 & 14.2 & - & 15.5 & - \\
\hline 1955 & 3.0 & 6.2 & -11.1 & 16.6 & - & 17.7 & - \\
\hline 1956 & -4.0 & 6.4 & -14.4 & 16.7 & - & 16.5 & 23.4 \\
\hline 1957 & -1.2 & 2.9 & -11.1 & 15.9 & - & 13.9 & 14.6 \\
\hline 1958 & 21.9 & 2.9 & -10.0 & 15.0 & - & 12.9 & 37.6 \\
\hline 1959 & 23.8 & 6.5 & -9.0 & 13.1 & - & 13.7 & 25.3 \\
\hline 1960 & -0.0 & 10.2 & -11.1 & 13.5 & - & 15.3 & 5.8 \\
\hline 1961 & -0.2 & 13.9 & -12.1 & 15.6 & - & 14.9 & 4.4 \\
\hline 1962 & 3.3 & 12.4 & -12.1 & 16.4 & - & 12.9 & 22.8 \\
\hline 1963 & 9.5 & 11.4 & -11.0 & 14.2 & - & 13.3 & 15.5 \\
\hline 1964 & -3.7 & 16.4 & -12.0 & 15.5 & - & 16.1 & 4.4 \\
\hline 1965 & 6.2 & 12.6 & -12.0 & 16.9 & - & 15.4 & 13.4 \\
\hline 1966 & -3.1 & 8.0 & -12.9 & 16.1 & - & 15.1 & 7.8 \\
\hline 1967 & 19.4 & 11.7 & -11.7 & 14.6 & - & 12.4 & 21.2 \\
\hline 1968 & 22.2 & 11.8 & -13.9 & 16.9 & - & 16.4 & 19.5 \\
\hline 1969 & -7.4 & 17.0 & -14.5 & 17.4 & - & 16.1 & 2.1 \\
\hline 1970 & -1.5 & 11.4 & -16.5 & 18.3 & - & 19.5 & 8.2 \\
\hline 1971 & 27.6 & 20.6 & -17.5 & 21.1 & - & 18.9 & 34.4 \\
\hline 1972 & 12.9 & 41.1 & -13.8 & 19.0 & - & 20.1 & 15.4 \\
\hline 1973 & -20.2 & 46.1 & -15.8 & 20.7 & - & 20.2 & -6.5 \\
\hline 1974 & -28.0 & 20.7 & -24.9 & 27.0 & - & 23.8 & -22.8 \\
\hline 1975 & 83.5 & 17.5 & -31.6 & 34.6 & - & 31.4 & 63.3 \\
\hline 1976 & -0.5 & 18.6 & -19.9 & 27.5 & - & 22.0 & 9.5 \\
\hline 1977 & 36.4 & 18.2 & -25.7 & 26.9 & - & 16.4 & 46.1 \\
\hline 1978 & 5.3 & 34.3 & -19.2 & 20.0 & 18.1 & 19.5 & 13.4 \\
\hline 1979 & 5.9 & 39.3 & -20.9 & 24.6 & 20.5 & 21.6 & 13.4 \\
\hline 1980 & 22.1 & 20.7 & -22.1 & 28.8 & 25.1 & 26.0 & 26.1 \\
\hline 1981 & 6.4 & 13.1 & -14.8 & 23.3 & 18.3 & 19.2 & 11.8 \\
\hline 1982 & 22.6 & 15.8 & -12.8 & 20.4 & 15.6 & 16.4 & 33.0 \\
\hline 1983 & 18.7 & 23.1 & -12.7 & 16.8 & 15.4 & 15.6 & 20.8 \\
\hline 1984 & 19.7 & 24.9 & -12.5 & 17.2 & 13.4 & 13.6 & 19.4 \\
\hline 1985 & 14.9 & 20.2 & -12.8 & 18.1 & 15.4 & 15.6 & 17.9 \\
\hline
\end{tabular}


The Impact of Wealth on Consumption and Retirement Behaviour in the UK 33

$\begin{array}{llllllll}1986 & 18.4 & 23.0 & -11.1 & 15.8 & 15.0 & 15.1 & 21.0 \\ 1987 & 4.7 & 27.5 & -12.1 & 14.8 & 15.0 & 15.0 & 14.8 \\ 1988 & 5.8 & 41.5 & -16.2 & 17.1 & 16.1 & 15.7 & 15.0 \\ 1989 & 25.5 & 14.3 & -22.5 & 19.6 & 16.5 & 16.1 & 24.9 \\ 1990 & -11.8 & 5.8 & -24.0 & 21.1 & 16.8 & 16.5 & -1.9 \\ 1991 & 10.2 & 6.3 & -12.3 & 17.9 & 15.4 & 15.2 & 15.3 \\ 1992 & 16.1 & 0.2 & -11.4 & 16.1 & 13.8 & 13.7 & 17.5 \\ 1993 & 23.6 & 6.4 & -7.9 & 14.2 & 11.9 & 11.6 & 24.6 \\ 1994 & -8.4 & 7.9 & -12.3 & 14.9 & 11.4 & 11.2 & -4.1\end{array}$

Note:

For definitions of variables, see Table 6.1. 
The Impact of Wealth on Consumption and Retirement Behaviour in the UK 34

Table 6.3 Summary Statistics 1949-94

\begin{tabular}{|c|c|c|c|c|}
\hline Variable & Units & Mean & $\begin{array}{l}\text { Standard } \\
\text { deviation }\end{array}$ & $\begin{array}{l}\text { Dickey Fuller } \\
\text { test }^{1}\end{array}$ \\
\hline$C$ & $\begin{array}{l}£^{\prime} 000(1990) \\
\text { per capita }\end{array}$ & 5.4687 & 1.4116 & -1.8565 \\
\hline$W$ & $\begin{array}{l}£^{\prime} 000(1990) \\
\text { per capita }\end{array}$ & 157.3242 & 60.3185 & -1.2538 \\
\hline$W_{F}$ & $\begin{array}{l}£^{\prime} 000(1990) \\
\text { per capita }\end{array}$ & 9.2703 & 1.7325 & -0.4166 \\
\hline$W_{H}$ & $\begin{array}{l}£^{\prime} 000(1990) \\
\text { per capita }\end{array}$ & 9.3330 & 5.9254 & -2.1535 \\
\hline$W_{D}$ & $\begin{array}{l}£ ' 000(1990) \\
\text { per capita }\end{array}$ & 3.1392 & 0.5285 & -3.1187 \\
\hline$W_{B}$ & $\begin{array}{l}£^{\prime} 000(1990) \\
\text { per capita }\end{array}$ & 7.8239 & 3.2551 & $-4.4984^{*}$ \\
\hline$W_{S}^{2}$ & $\begin{array}{l}£ ’ 000(1990) \\
\text { per capita }\end{array}$ & 2.0103 & 1.1160 & -3.4015 \\
\hline$W_{O}$ & $\begin{array}{l}£^{\prime} 000(1990) \\
\text { per capita }\end{array}$ & 5.0093 & 4.3860 & -0.6882 \\
\hline$S U R P L U S$ & $\begin{array}{l}£^{\prime} 000(1990) \\
\text { per capita }\end{array}$ & 0.3287 & 1.1571 & -1.9433 \\
\hline$W_{P}^{3}$ & $\begin{array}{l}£^{\prime} 000(1990) \\
\text { per capita }\end{array}$ & 0.2118 & 0.3750 & 2.5998 \\
\hline$\Delta W_{P}^{4}$ & $\begin{array}{l}£^{\prime} 000(1990) \\
\text { per capita }\end{array}$ & 0.0377 & 0.0818 & $-4.3385^{*}$ \\
\hline$W_{L}$ & $\begin{array}{l}£^{\prime} 000(1990) \\
\text { per capita }\end{array}$ & 120.5421 & 45.6424 & -1.5239 \\
\hline$r_{W}$ & $\%$ (real) & 3.0760 & 1.2630 & $-4.7939^{*}$ \\
\hline$r_{F}$ & $\%$ (real) & 1.6139 & 14.7438 & $-7.3946^{*}$ \\
\hline$r_{H}$ & $\%$ (real) & 6.0400 & 9.4618 & $-3.7222^{*}$ \\
\hline$r_{D}$ & $\%$ (real) & -22.5014 & 10.7200 & -2.9182 \\
\hline$r_{B}$ & $\%$ (real) & 10.6401 & 0.8453 & $-3.5088^{*}$ \\
\hline$r_{S}^{2}$ & $\%$ (real) & 8.2742 & 1.8795 & -2.4077 \\
\hline$r_{O}$ & $\%$ (real) & 9.0967 & 2.3376 & $-4.2358^{*}$ \\
\hline$r_{p}^{3}$ & $\%($ real $)$ & 8.0440 & 12.9103 & $-6.2714^{*}$ \\
\hline$Y$ & $\begin{array}{l}£^{\prime} 000(1990) \\
\text { per capita }\end{array}$ & 5.9902 & 1.6410 & -2.3253 \\
\hline$Y V O L$ & $\%$ & 1.4986 & 1.2818 & $-5.8358^{*}$ \\
\hline$\dot{P}_{F}$ & $\begin{array}{l}£^{\prime} 000(1990) \\
\text { per capita }\end{array}$ & 0.5492 & 0.3318 & -2.7730 \\
\hline
\end{tabular}


The Impact of Wealth on Consumption and Retirement Behaviour in the UK 35

$\begin{array}{lllll}\triangle U N & \% & 0.1696 & 0.9770 & -3.6043^{*} \\ \text { LABPR } & \% & 78.9414 & 1.8455 & -1.8642 \\ \text { AGEPR } & \% & 12.3213 & 3.1226 & -1.3537 \\ \text { YOUTHDR } & \% & 21.8872 & 1.7647 & -1.8947 \\ \text { LIFEXP } & \text { Years } & 79.7223 & 1.0707 & -3.6444^{*} \\ \text { SG } & £ ' 000(1990) & 0.0536 & 0.2492 & -1.5070 \\ & \text { per capita } & & & \\ \text { SC } & £^{\prime} 000(1990) & 0.7569 & 0.2515 & -2.9864 \\ & \text { per capita } & & & \end{array}$

Notes:

1 Dickey Fuller test with trend; critical value -3.5088; asterisk indicates variable is stationary about trend, all other variables are nonstationary.

2 From 1979

3 From 1956

4 From 1957. 


\section{REFERENCES}

[1] Abadir, K.M., Hadri, K., and Tzavalis, E. (1999) The influence of VAR dimensions on estimator biases, Econometrica, 67, 163-81.

[2] Alessie, R., Devereux, M.P., and Weber, G. (1997) Intertemporal consumption, durables and liquidity constraints: A cohort analysis, European Economic Review, $41,37-59$.

[3] Attanasio, O.P., and Weber, G. (1994) The UK consumption boom of the late 1980s: Aggregate implications of microeconomic evidence, Economic Journal, 104, 12691302.

[4] Barro, R.J. (1974) Are government bonds net wealth?, Journal of Political Economy, $82,1095-117$.

[5] Barro, R. (1978) The Impact of Social Security on Private Saving, American Enterprise Institute, Washington, DC.

[6] Bayoumi, T. (1993a) Financial deregulation and consumption in the United Kingdom, Review of Economics and Statistics, 75, 536-9.

[7] Bayoumi, T. (1993b) Financial deregulation and household saving, Economic Journal, 103, 1432-43.

[8] Bayoumi, T. (1995) Explaining consumption: A simple test of alternative hypotheses, Discussion Paper 1289, Centre for Economic Policy Research, London, December.

[9] Bayoumi, T., and Koujianou, P. (1991) Consumption, liquidity constraints and financial deregulation, Greek Economic Review, 12, 195-210.

[10] Bewley, R.A. (1979) The direct estimation of the equilibrium response in a linear model, Economic Letters, 3, 357-61.

[11] Blake, D., and Orszag, M. (1999) Annual estimates of personal wealth holdings in the UK since 1948, Applied Financial Economics, 9, 397-421.

[12] Blinder, A., Gordon, R., and Wise, D. (1980) Reconsidering the disincentive effects of social security, National Tax Journal, 33, 431-42.

[13] Blinder, A., Gordon, R., and Wise, D. (1983) Social security bequests and the life cycle theory of saving: Cross-sectional tests, in Modigliani, F. and Hemming, R. (eds.) The Determinants of National Savings and Wealth, St. Martin's Press, New York, 89-122.

[14] Blundell, R., Pashardes, P., and Weber, G. (1993) What do we learn about consumer demand patterns from microdata?, American Economic Review, 83, 570-97.

[15] Boskin, M.J. (1977) Social security and retirement decisions, Economic Inquiry, 15, $1-25$.

[16] Boskin, M.J., and Hurd, M.D. (1978) The effect of social security on early retirement, Journal of Public Economics, 10, 361-77. 
[17] Browning, M.J. (1982) Savings and pensions: Some UK evidence, Economic Journal, 92, 954-63.

[18] Burkhauser, R., and Turner, J. (1982) Social security, preretirement labour supply and saving: A confirmation and critique, Journal of Political Economy, 90, 643-6.

[19] Caballero, R. (1990) Consumption puzzles and precautionary savings, Journal of Monetary Economics, 25, 113-36.

[20] Cagan, P. (1965) The Effect of Pension Plans on Aggregate Savings, National Bureau of Economic Research, New York.

[21] Campbell, J.Y., and Mankiw, N.G. (1991) The response of consumption to income: A cross-country investigation, European Economic Review, 35, 723-67.

[22] Cochrane, J.H. (1991) A simple test of consumption insurance, Journal of Political Economy, 99, 957-76.

[23] Crawford, P.C., and Lilien, D.M. (1981) Social security and the retirement decision, Quarterly Journal of Economics, 46, 505-29.

[24] Cushing, M.J. (1992) Liquidity constraints and aggregate consumption behaviour, Economic Inquiry, 30, 134-53.

[25] Danziger, S., van der Gaag, J., Smolensky, E., and Taussig, M. (1982-83) The life cycle hypothesis and the consumption behaviour of the elderly, Journal of PostKeynesian Economics, 5, 208-27.

[26] Darby, M. (1979) The Effects of Social Security on Income and the Capital Stock, American Enterprise Institute, Washington, DC.

[27] David, M., and Menchik, P. (1985) The effect of social security on lifetime wealth accumulation and bequests, Economica, 52, 421-34.

[28] Disney, R., Meghir, C., and Whitehouse, E. (1994) Retirement behaviour in Britain, Fiscal Studies, 15, 24-43.

[29] Edwards, S. (1996) The Chilean pension reform: A pioneering programme, NBER Working Paper No.5811.

[30] Fama, E.F., and Schwert, G.W. (1977) Human capital and capital market equilibrium, Journal of Financial Economics, 4, 95-125.

[31] Feldstein, M. (1974) Social security, induced retirement and aggregate capital accumulation, Journal of Political Economy, 82, 905-26.

[32] Feldstein, M. (1976) Social security and savings: The extended life cycle theory, American Economic Review, Papers and Proceedings, 66, 77-86.

[33] Feldstein, M. (1978) Do private pensions increase national savings? Journal of Public Economics, 10, 277-93.

[34] Feldstein, M. (1979) Social security and private saving: Another look, Social Security Bulletin, 42, 36-39. 
[35] Feldstein, M. (1980) International differences in social security and savings, Journal of Public Economics, 14, 225-44.

[36] Feldstein, M. (1982) Social security and private saving: Reply, Journal of Political Economy, 90, 630-42.

[37] Feldstein, M. (1997) The case for privatisation, Foreign Affairs, 76, 24-38.

[38] Feldstein, M., and Bacchetta, P. (1991) National savings and international investment, in Bernheim, B., and Shoven, J. (eds.) National Saving and Economic Performance, University of Chicago Press, Chicago.

[39] Flavin, M. (1985) Excess sensitivity of consumption to current income: Liquidity constraints or myopia?, Canadian Journal of Economics, 18, 117-36.

[40] Friedman, B., and Warshawsky, M. (1990) The cost of annuities: Implications for saving behaviour and bequests, Quarterly Journal of Economics, 105, 135-54.

[41] Gale, W., and Scholz, J. (1994) IRAs and household saving, American Economic Review, 84, 1233-60.

[42] Gonzalo, J., and Lee, T-H. (1998) Pitfalls in testing for long-run relationships, Journal of Econometrics, 86, 129-54.

[43] Goodman, A., Johnson, P. and Webb, S. (1997) Inequality in the UK, Oxford University Press, Oxford.

[44] Green, F. (1981) The effect of occupational pension schemes on saving in the United Kingdom: A test of the life cycle hypothesis, Economic Journal, 91, 136-44.

[45] Hall, R.E. (1978) Stochastic implications of the life cycle - permanent income hypothesis: Theory and evidence, Journal of Political Economy, 86, 971-87.

[46] Hamermesh, D. (1985) Expectations, life expectancy and economic behaviour, Quarterly Journal of Economics, 100, 389-408.

[47] Hendry, D.F. (1994) HUS revisited, Oxford Review of Economic Policy, 10, 86-106.

[48] Hendry, D.F., and von Ungern-Sternberg, T. (1981) Liquidity and inflation effects on consumers' expenditure, in Deaton, A.S. (ed.) Essays in the Theory and Measurement of Consumer Behaviour, Cambridge University Press, Cambridge.

[49] Hemming, R. (1978) State pensions and personal savings, Scottish Journal of Political Economy, 25, 135-47.

[50] Hemming, R., and Harvey, R. (1983) Occupational pension scheme membership and retirement saving, Economic Journal, 93, 128-44.

[51] Holzman, R. (1997) Pension reform, financial market development and economic growth: Preliminary evidence from Chile, IMF Staff Papers, 44, 149-178.

[52] Horioka, C., Kasuga, N., Yamazaki, K., and Watanabe, W. (1996) Do the aged dissave in Japan?: Evidence from micro data, University of Kobe Institute of Social and Economic Research Discussion Paper No.402. 
[53] Hurd, M. (1987) Savings of the elderly and desired bequests, American Economic Review, 77, 298-312.

[54] Jagannathan, R., and Wang, Z. (1994), Conditional CAPM is alive and well, University of Minnesota Discussion Paper, Minneapolis.

[55] Katona, G. (1964) Private Pensions and Individual Savings, Survey Research Center, Institute for Social Research, University of Michigan.

[56] Kotlikoff, C.J. (1979) Testing a theory of social security and life cycle accumulation, American Economic Review, 69, 396-410.

[57] Kotlikoff, L., and Summers, L. (1981) The role of intergenerational transfers in aggregate capital accumulation, Journal of Political Economy, 89, 706-32.

[58] Kurz, M. (1984) Capital accumulation and the characteristics of private intergenerational transfers, Economica, 51, 1-22.

[59] Laitner, J., and Juster, F.T. (1996) New evidence on altruism: A study of TIAACREF retirees, American Economic Review, 86, 893-908.

[60] Leimer, D., and Lesnoy, S. (1982) Social security and private saving: New time series evidence, Journal of Political Economy, 90, 606-42.

[61] Leimer, D., and Richardson, D. (1992) Social security, uncertainty adjustments and the consumption decision, Economica, 59, 311-36.

[62] Mace, B. (1991) Full insurance in the presence of aggregate uncertainty, Journal of Political Economy, 99, 928-56.

[63] Manchester, J., and Poterba, J. (1989) Second mortgages and household savings, NBER Discussion Paper No.2853, Cambridge, Mass.

[64] Meghir, C., and Whitehouse, E. (1997) Labour market transitions and the retirement of men in the UK, Journal of Econometrics, 79, 327-54.

[65] Merton, R.C. (1969) Lifetime portfolio selection under uncertainty: The continuoustime case, Review of Economics and Statistics, 51, 247-57.

[66] Merton, R.C. (1971) Optimum consumption and portfolio rules in a continuous-time model, Journal of Economic Theory, 3, 373-413.

[67] Miles, D. (1992) Housing markets, consumption and financial liberalization in the major economies, European Economic Review, 36, 1-36.

[68] Miles, D., and Patel, B. (1996) Savings and wealth accumulation in Europe, Merrill Lynch Financials Research, London, June.

[69] Mirer, T. (1979) The wealth-age relation among the aged, American Economic Review, 69, 435-43.

[70] Modigliani, F. (1970) The life-cycle hypothesis of saving and intercountry differences in the savings ratio, in Eltis, W.A., Scott, F.G., and Wolfe, J.N. (eds.) Induction, Growth and Trade: Essays in Honour of Sir Roy Harrod, Clarendon Press, Oxford, 197-226. 
The Impact of Wealth on Consumption and Retirement Behaviour in the UK 40

[71] Muellbauer, J., and Murphy, A. (1993) Income expectations, wealth and demography in the aggregate UK consumption function, Nuffield College, Oxford.

[72] Munnell, A. (1974) The Effect of Social Security on Personal Saving, Ballinger, Cambridge, Mass.

[73] Pesaran, M.H., and Pesaran, B. (1997) Microfit 4.0, Oxford University Press, Oxford.

[74] Pesaran, M.H., and Shin, Y. (1997) An autoregressive distributed lag model approach to cointegration analysis, in Strom, S., Holly, A., and Diamond, P. (eds.) Centennial Volume of Ragnar Frisch, Cambridge University Press, Cambridge.

[75] Pitelis, C.N. (1985) The effects of life assurance and pension funds on other savings: The post-war UK experience, Bulletin of Economic Research, 37, 213-29.

[76] Poterba, J., Venti, S., and Wise, D. (1996) Personal retirement savings programs and asset accumulation: Reconciling the evidence, NBER Working Paper No.5599.

[77] Sheshinski, E. (1978) A model of social security and retirement decisions, Journal of Public Economics, 10, 337-60.

[78] Shiller, R.J. (1993) Aggregate income risks and hedging mechanisms, NBER Discussion Paper No. 4396, Cambride, Mass.

[79] Skinner, J. (1988) Risk income, life cycle consumption and precautionary savings, Journal of Monetary Economics, 22, 237-55.

[80] Stoker, T. (1986) Simple tests of distributional effects on macroeconomic equations, Journal of Political Economy, 94, 763-95.

[81] Takayama, N. (1990) How much do public pensions discourage personal savings and induce early retirement in Japan, Hitotsubashi Journal of Economics, 31, 87-104.

[82] Taylor, L. (1971) Saving out of different types of income, Brookings Papers on Economic Activity, 2, 383-407.

[83] Threadgold, A.R. (1978) Personal savings: the impact of life assurance and pension funds, Bank of England Discussion Paper No.1, October.

[84] Zeldes, S.P. (1989) Consumption and liquidity constraints: An empirical investigation, Journal of Political Economy, 97, 305-46. 
The Impact of Wealth on Consumption and Retirement Behaviour in the UK 41

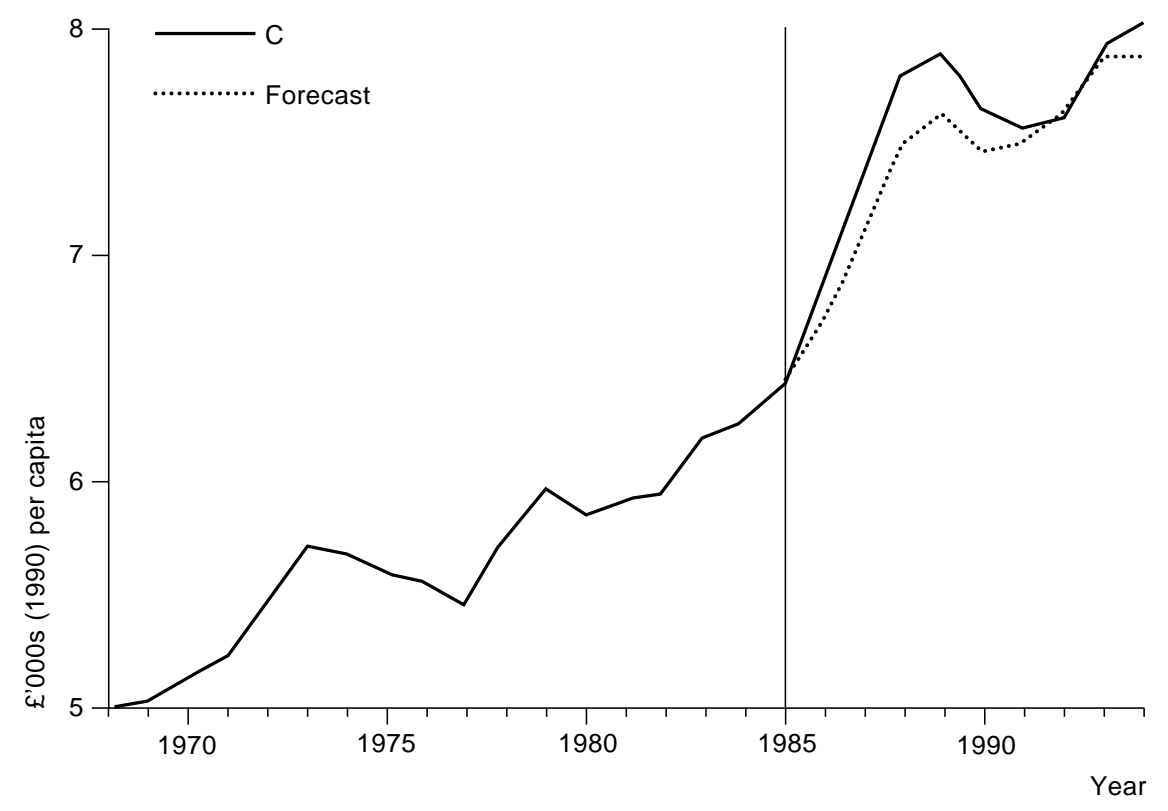

Figure 4.1: Actual and dynamic forecast of consumption (C(1) in Table 4.2), 1985-1994 
The Impact of Wealth on Consumption and Retirement Behaviour in the UK 42

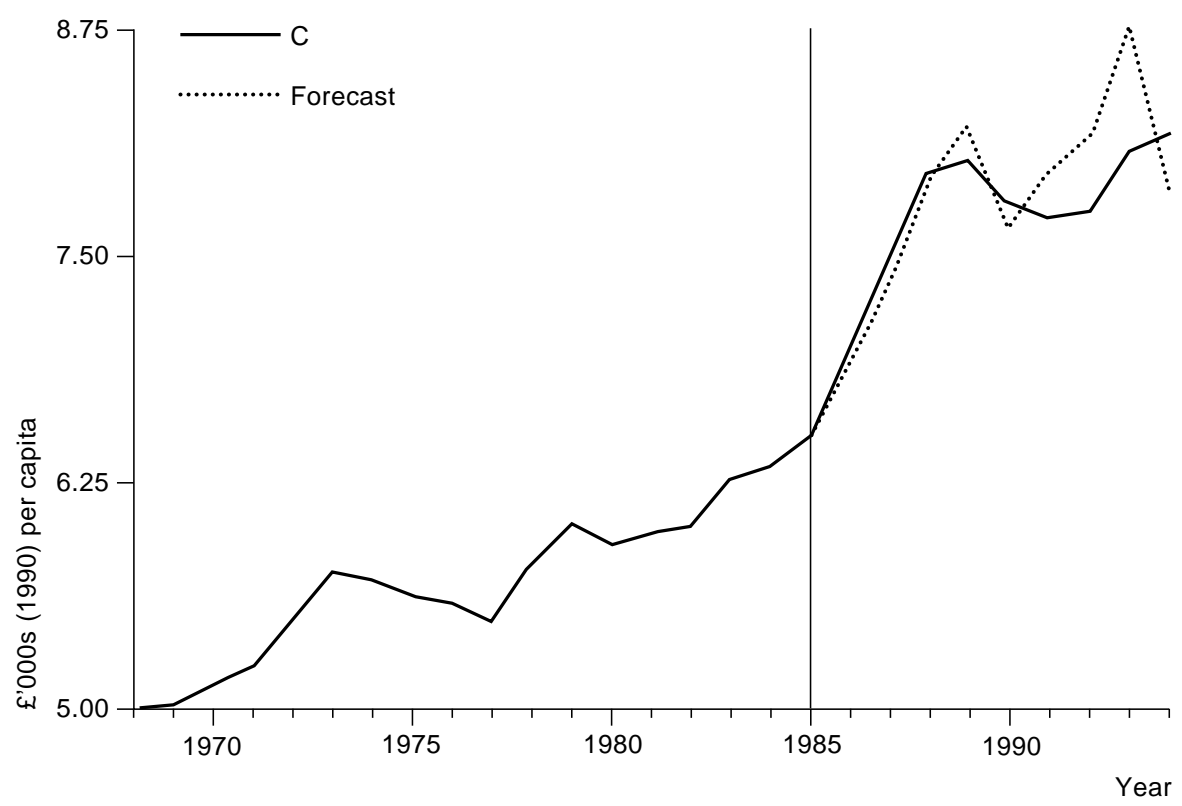

Figure 4.2: Actual and static forecast of consumption (C(2) in Table 4.2), 1985-1994

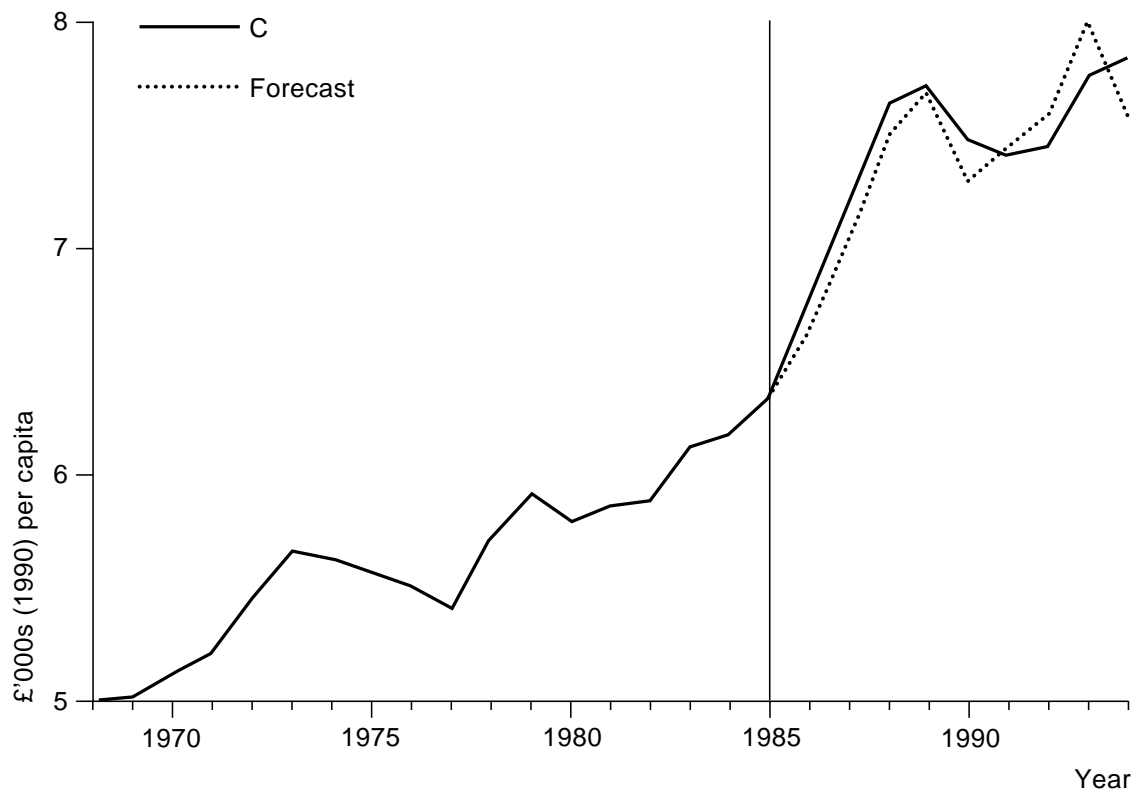

Figure 4.3: Actual and dynamic forecast of consumption (C(3) in Table 4.2), 1985-1994 
The Impact of Wealth on Consumption and Retirement Behaviour in the UK

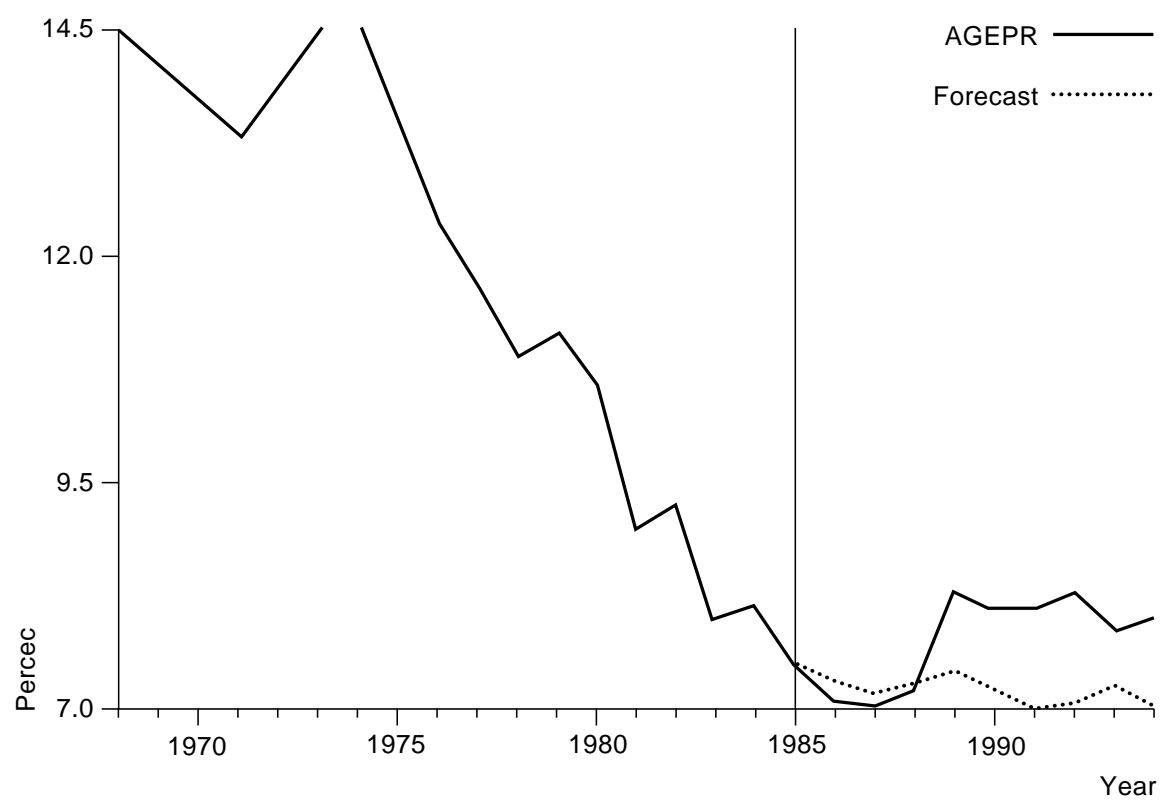

Figure 4.4: Actual and dynamic forecast of the elderly participation rate (AGEPR(1) in Table 4.4), 1985-1994 
The Impact of Wealth on Consumption and Retirement Behaviour in the UK 44

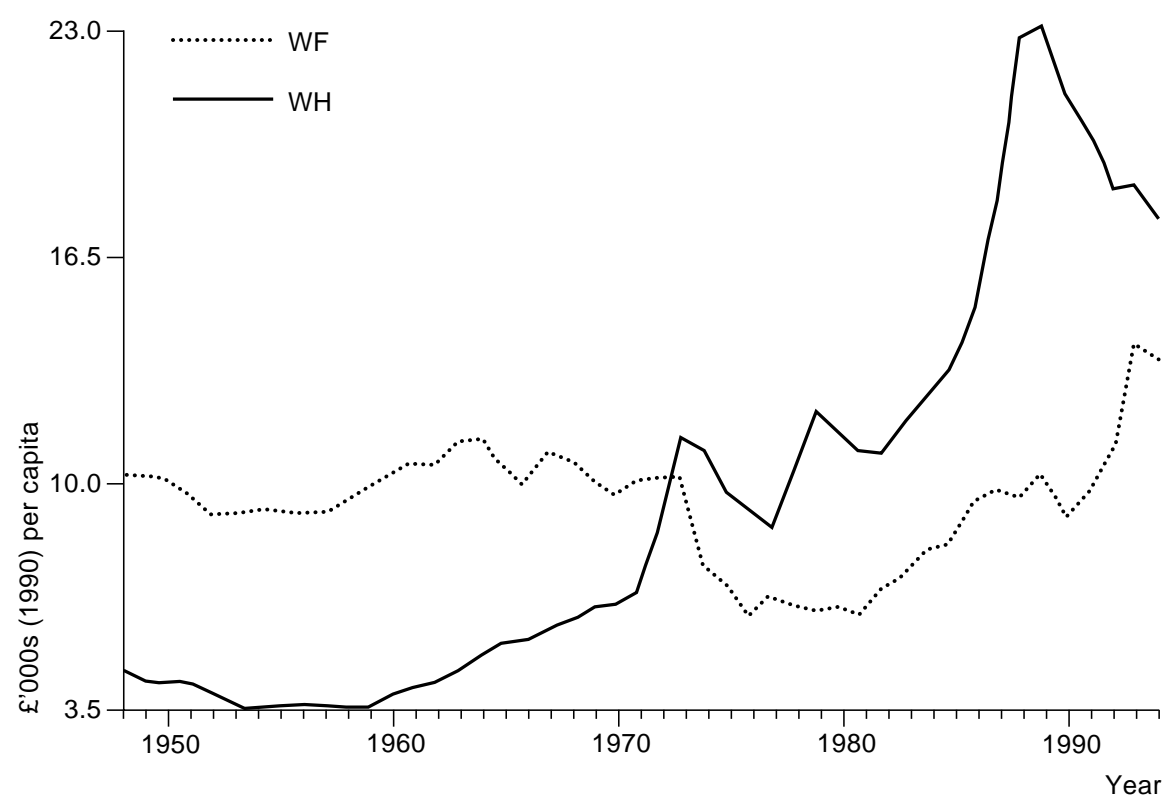

Figure 6.2: Net financial wealth and housing wealth, 1948-1994

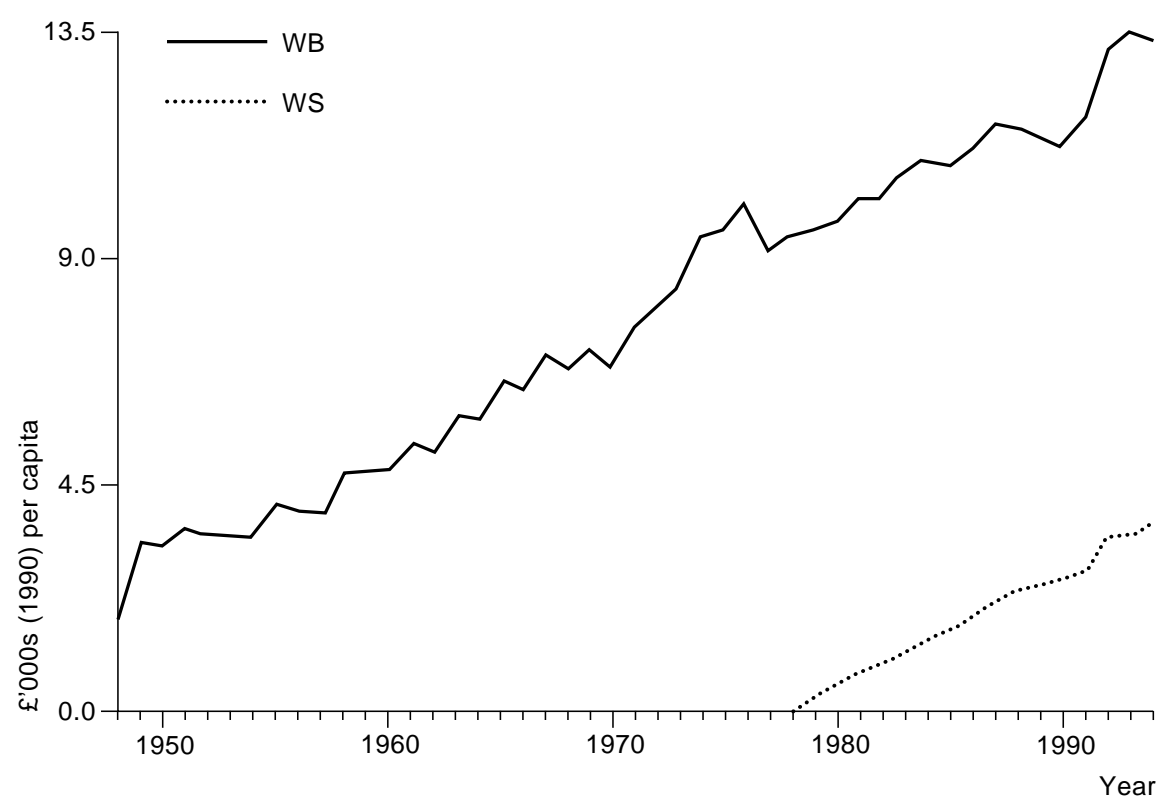

Figure 6.3: Basic state pension wealth and SERPS pension wealth, 1948-1994 
The Impact of Wealth on Consumption and Retirement Behaviour in the UK 45

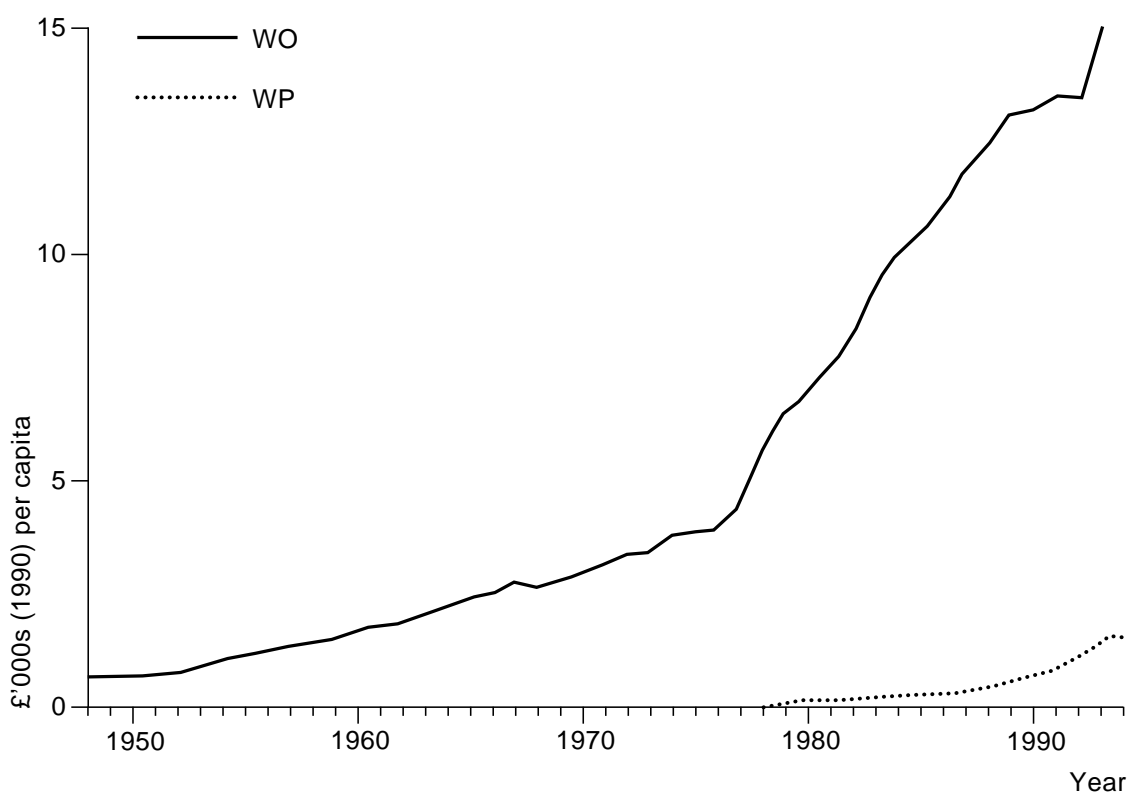

Figure 6.4: Occupational pension wealth and personal pension wealth, 1948-1994

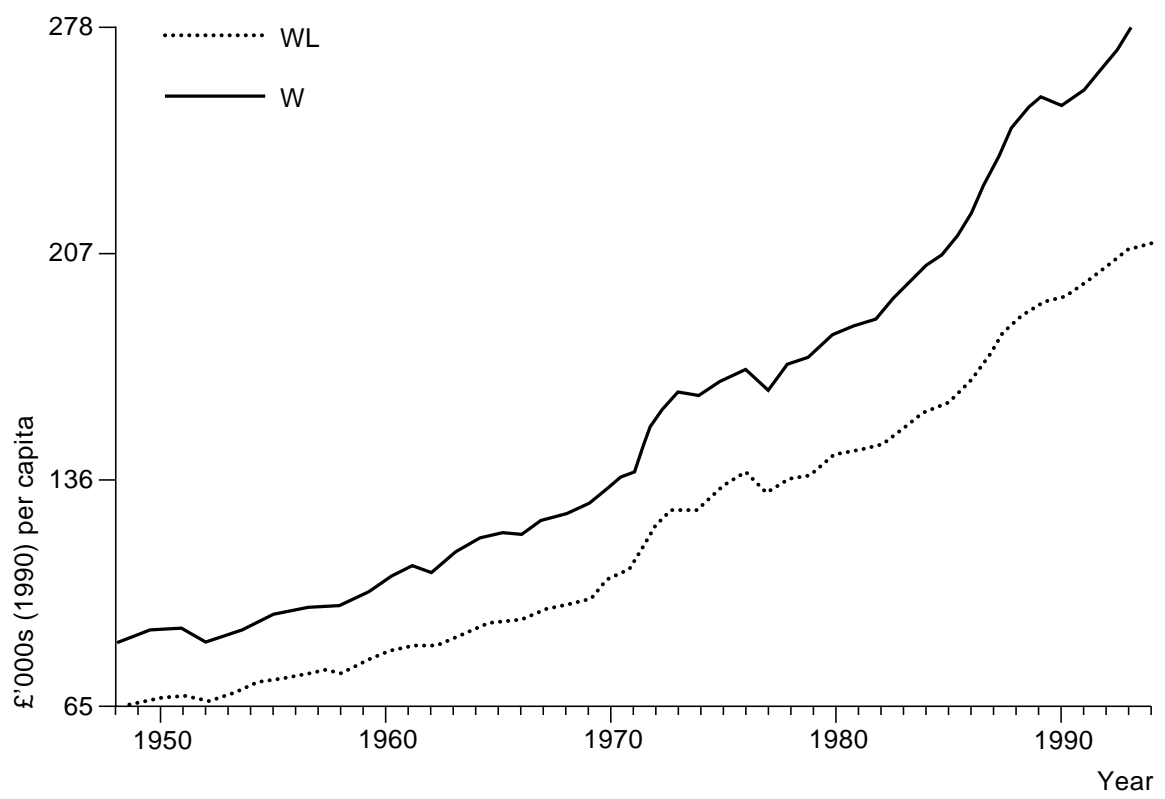

Figure 6.5: Human capital and total wealth, 1948-1994 
The Impact of Wealth on Consumption and RetiRement Behaviour in the UK 46

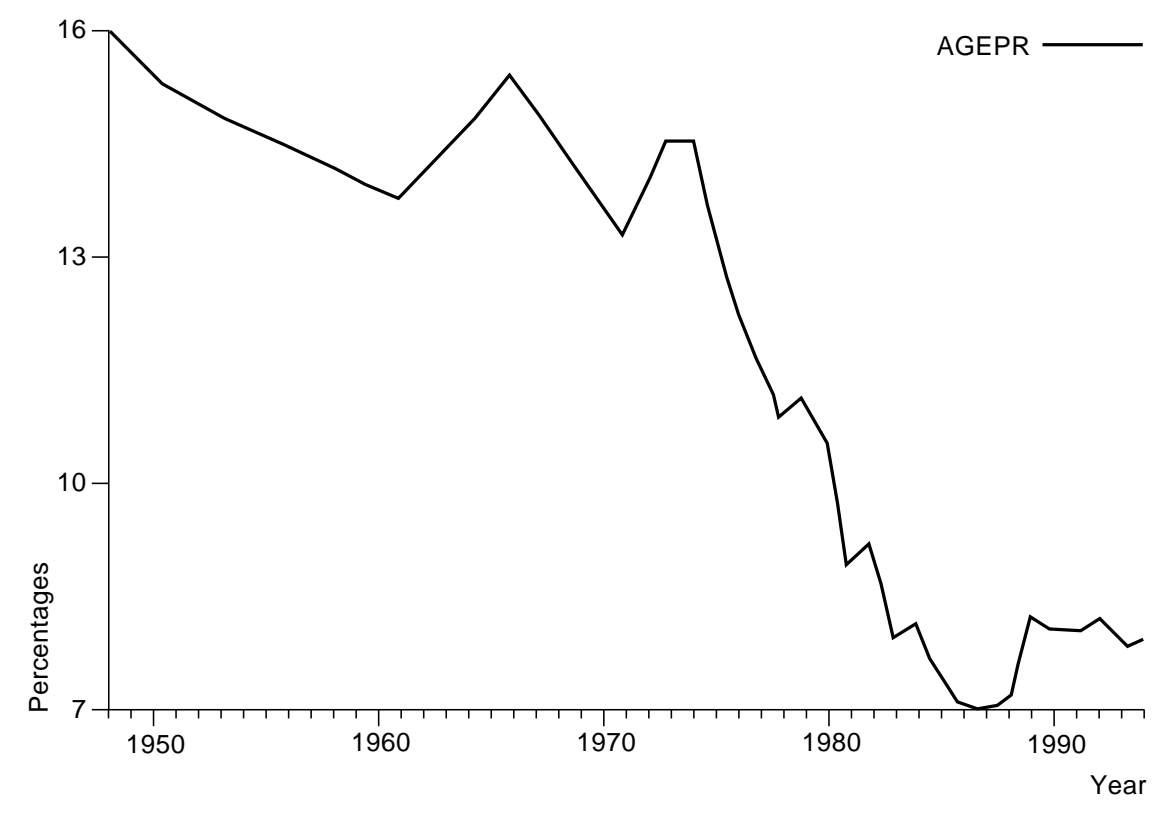

Figure 6.6: Elderly participation rate in the labour force, 1948-1994 